\title{
New and little known feather mites (Acariformes: Astigmata) analysed with low-temperature scanning electron microscopy
}

\author{
Fabio Akashi Hernandes, Gary R. Bauchan \& Ronald Ochoa
}

To cite this article: Fabio Akashi Hernandes, Gary R. Bauchan \& Ronald Ochoa (2017) New and little known feather mites (Acariformes: Astigmata) analysed with low-temperature scanning electron microscopy, International Journal of Acarology, 43:7, 499-517, DOI: 10.1080/01647954.2017.1367032

To link to this article: https://doi.org/10.1080/01647954.2017.1367032

巴nublished online: 22 Aug 2017.

Submit your article to this journal $\sqsubset$

Џ Article views: 94

View Crossmark data \lceil

Citing articles: 1 View citing articles 5 


\title{
New and little known feather mites (Acariformes: Astigmata) analysed with low-temperature scanning electron microscopy
}

\author{
Fabio Akashi Hernandes ${ }^{a}$, Gary R. Bauchan ${ }^{b}$ and Ronald Ochoa ${ }^{c}$

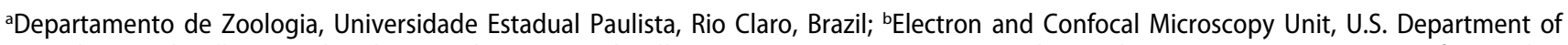 \\ Agriculture, Beltsville Agricultural Research Center, Beltsville, MD, USA; 'Systematic Entomology Laboratory, U.S. Department of Agriculture, \\ Beltsville Agricultural Research Center, Beltsville, MD, USA
}

\begin{abstract}
Feather mites (Acari: Astigmata) were analysed with low-temperature scanning electron microscopy, including the description of three new species: Plicatalloptes atrichogynus sp. nov. (Analgoidea: Alloptidae) from the Neotropical cormorant Phalacrocorax brasilianus (Gmelin) (Pelecaniformes: Phalacrocoracidae), Metapterodectes saturninus sp. nov. (Analgoidea; Proctophyllodidae) from the chalk-browed mockingbird Mimus saturninus (Lichtenstein) (Passeriformes: Mimidae), and Neumannella crypturella sp. nov. (Analgoidea: Dermoglyphidae) from the small-billed tinamou Crypturellus parvirostris (Wagler) (Tinamiformes: Tinamidae). In addition, two previously known species are analysed, Oustaletia pegasus Trouessart, 1855 (Pterolichoidea: Vexillariidae) from the bushycrested hornbill Anorrhinus galeritus (Temminck) (Bucerotiformes: Bucerotidae), and Opisthocomacarus umbellifer (Trouessart, 1899) (Pterolichoidea: Pterolichidae) from the hoatzin Opisthocomus hoazin (Müller) (Opisthocomiformes: Opisthocomidae). The latter two mite species display a rich variety of setal structures. Alloptes umbrettae Gaud, 1960 (Analgoidea: Alloptidae), known from Scopus umbretta Gmelin (Pelecaniformes: Scopidae), is transferred from the genus Alloptes Canestrini to Plicatalloptes Dubinin and given a new valid name, Plicatalloptes umbrettae (Gaud, 1960) comb. nov.

http://zoobank.org/urn:Isid:zoobank.org:pub:5866FF00-1206-4551-9544-8A002ADF7626
\end{abstract}

\section{ARTICLE HISTORY}

Received 5 June 2017

Accepted 7 August 2017

Published online 22 August 2017

\section{KEYWORDS}

Acari; morphology; systematics; parasites

\section{Introduction}

As Walter and Proctor $(2013,381)$ noted in their monograph on the ecology, evolution and behaviour of mites, feather mites (Acariformes: Astigmata: Analgoidea and Pterolichoidea) are "perhaps the most fabulously ornamented of all Acari." Outstanding examples of ornamentations can be seen in feather mites like Opisthocomacarus umbellifer (Trouessart, 1899) (Pterolichidae) and Oustaletia pegasus Trouessart, 1885 (Vexillariidae), having many dorsal setae variously modified into flattened, leaf-like and spiky structures which biological functions are yet a subject of speculation (Atyeo and Gaud 1971; Hernandes and Mironov 2015). Other odd feather mites can have dorsal shields adorned with longitudinal ridges (e.g. Protonyssus Trouessart, Xolalgidae; Atopolichus Gaud, Pterolichidae) (Mironov et al. 2005; Hernandes and Pedroso 2017), bullet-like protrusions (e.g. Aterolichus Gaud, Pterolichidae), or perforated with numerous large lacunae (e.g. Montesauria pardalis [Gaud and Mouchet 1957], Proctophyllodidae; O. umbellifer, Pterolichidae) (Gaud and Mouchet 1957; Gaud and Atyeo 1996).

Many of such remarkable examples of rich feather mite morphology have been investigated in closer detail using scanning electron microscopy (SEM) in a number of studies (e.g. Atyeo and Gaud 1971; Atyeo et al. 1972; Kudon 1982; Atyeo 1988a, 1988b, 1992; Pérez and Atyeo 1992; Pérez 1995; Gaud and Atyeo 1996; Mestre et al. 2011; Albuquerque et al. 2012; Hernandes et al. 2015, 2016a). This technique has provided high-quality images of mites, often revealing morphological features previously unsuspected with traditional optical microscopy, e.g. the gecko-skin like texture of the pseudo-rutelar processes of Michaelia neotropica Hernandes \& Mironov, 2016 Freyanidae (Hernandes et al. 2016a).
In the present work, various feather mites are analysed with the SEM technique, in addition to the standard optical microscopy. Three new species belonging to the genera Plicatalloptes Dubinin (Analgoidea: Alloptidae), Metapterodectes Mironov (Analgoidea: Proctophyllodidae), and Neumannella Trouessart (Analgoidea: Pyroglyphidae) are described from the Neotropical cormorant Phalacrocorax brasilianus (Gmelin) (Pelecaniformes: Phalacrocoracidae), the chalk-browed mockingbird, Mimus saturninus (Lichtenstein) (Passeriformes: Mimidae), and the small-billed tinamou, Crypturellus parvirostris (Wagler) (Tinamiformes: Tinamidae), respectively. In addition, Oustaletia pegasus (Vexillaridae) and Opistho comacarus umbellifer (Pterolichidae) are also analysed with this technique.

\section{Materials and methods}

The feather mites studied herein were obtained from two sources: (1) dead specimens of birds sent to the laboratory of Acarology of Department of Zoology of the Universidade Estadual Paulista, Rio Claro, São Paulo, Brazil; (2) museum bird skins from the collections of the Museum of Zoology of the University of Michigan (UMMZ), Ann Arbor, Michigan, USA, and the Field Museum of Natural History (FMNH), Chicago, Illinois, USA. The collection from the museum skins followed the procedures described in Gaud and Atyeo (1996). In both cases, mites were manually collected under a dissecting microscope with the aid of a fine brush, cleared in 30\% lactic acid for $24 \mathrm{~h}$ at $50^{\circ} \mathrm{C}$, and mounted in Hoyer's medium according to the standard technique for small acariform mites (Krantz and Walter 2009). After five days at $50^{\circ} \mathrm{C}$, the 
slides were sealed with varnish. Drawings and measurements of mites were made with a Leica DM3000 microscope equipped with differential interference contrast optics and a camera lucida. Pencil sketches were scanned at 300-dpi grayscale and line drawings were created with Adobe Illustrator CS6 and a Wacom Bamboo Create tablet. The idiosoma and leg chaetotaxy follow Griffiths et al. (1990) and Atyeo and Gaud (1966), respectively, with corrections for coxal setae proposed by Norton (1998). Descriptions of the new species follow the scheme proposed by the most recent descriptions of the relevant or similar taxa (Mironov and Palma 2006; Dabert 2014; Hernandes et al. 2016b).

Specimens were observed by low-temperature scanning electron microscopy (LT-SEM) following the technique described in Castro et al. (2015) and Hernandes et al. (2016a). Mites collected from museum skins were directly subject to the SEM technique withouth cleaning or ultrasound processing. Specimens collected from frozen birds were stored in ethanol $70 \%$ prior to the SEM technique. Type specimens are deposited at DZUnesp-RC Collection of Acari of Department of Zoology of the Universidade Estadual Paulista, Rio Claro, São Paulo, Brazil USNM - National Insect and Mite Collection, National Museum of Natural History, Smithsonian Institution, located at the SELUSDA, Beltsville, Maryland, USA; UMMZ - Museum of Zoology, the University of Michigan (Ann Arbor, USA); OSAL-The Acarology Laboratory, Museum of Biological Diversity, The Ohio State University, Columbus, USA; ZISP - Zoological institute, Russian Academy of Sciences, Saint Petersburg, Russia; MNHN Muséum National d'Histoire Naturelle, Paris, France; MGAB Acarological Collection of the "Grigore Antipa" National Museum of Natural History, Bucharest, Romania.

\section{Superfamily Analgoidea Trouessart \& Mégnin, 1884 Family Alloptidae Gaud, 1957 Subfamily Alloptinae Gaud, 1957 Genus Plicatalloptes Dubinin, 1955}

Type species: Plicatalloptes plegadis Dubinin, 1955, by original designation.

The genus Plicatalloptes was erected by Dubinin (1955) to accommodate a single species, P. plegadis Dubinin, 1955 from Plegadis falcinellus (Linnaeus, 1766) (Pelecaniformes: Threskiornithidae). Gaud and Till $(1961,240)$ expressed doubts about the validity of this and several other genera erected by Dubinin $(1951,1955)$, and Gaud $(1982,706)$ regarded Plicatalloptes as a synonym of Alloptes Canestrini, 1879 based on the fact that the unusual opisthosomal appearance of the male holotype of Plicatalloptes plegadis was caused by an incomplete moult of specimen still being inside the tritonymphal exuvia. Mironov (1996) revalidated the genus Plicatalloptes and, in addition to the type species, transferred to this genus five Alloptes species described from ibises (Threskiornithidae), cormorants (Phalacrocoracidae), and pelicans (Pelecanidae): P. stenurus (Gaud \& Mouchet, 1957), P. plataleae (Gaud, 1982), P. subcrassipes (Dubinin \& Dubinina, 1940), P. ferrandi (Gaud \& Mouchet, 1957), and P. pelecani (Dubinin, 1954). Further, Mironov $(2002,41)$ referred Alloptes trachelurus Trouessart, 1885 to the genus Plicatalloptes, but this was an incorrect solution. Later on it was found (Mironov 2013) that this species is the senior synonym of Anisanchus ptilotus Peterson \& Atyeo, 1977, the type species of the genus Anisanchus Peterson \& Atyeo, 1977. Plicatalloptes umbrettae (Gaud, 1960) comb. nov., known from Scopus umbretta Gmelin, 1789 (Pelecaniformes: Scopidae) is herein transferred from Alloptes, based on examination of the type specimens housed at the Royal Museum for Central Africa, Tervuren, Belgium.

Thus, the genus Plicatalloptes presently comprises eigth species, including the new one described in the following. The most clear feature of Plicatalloptes distinguishing it from the genus Alloptes is the presence of a lateral crest or fold on tarsi III and IV of females (Mironov 1996, 1998) (Figures 3(g,h) and $4(d)$ ).

\section{Plicatalloptes atrichogynus Hernandes sp. nov.}

(Figures 1-4)

\section{Type material}

Holotype male (DZUNESP-RC \# 3908), paratypes 31 males and 54 females ex Phalacrocorax brasilianus (Gmelin, 1789) (Pelecaniformes: Phalacrocoracidae), 2009, Pedreira, São Paulo State, Brazil, $22^{\circ} 44^{\prime}$ S, $46^{\circ} 54^{\prime} \mathrm{W}$, David V. Boas-Filho col. (\#390).

\section{Type deposition}

Holotype male at DZUnesp-RC; paratypes at DZUnesp-RC, DZSJRP, ZISP, UMMZ, USNM, OSAL, MNHN, MGAB.

Male. (Figures 1, 3(a-d and 4(a)); holotype, range for 7 paratypes in parentheses. Idiosoma size, length $\times$ width, $330 \times 150(327-343 \times 140-156)$. Prodorsal shield: posterior margin concave, surface without ornamentation, greatest length 84 (78-86), width of posterior part 76 (73-80), distance between setae se 81 (71-83). Length of hysterosoma from sejugal furrow to bases of setae ps1 238 (236-246). Hysteronotal shield (Figure 1(a)): greatest length from anterior end to bases of setae ps1 222 (222-241), width of anterior part 76 (76 - 82), anterior margin slightly concave, anterolateral corners acute, lateral margin with small incision at level of trochanters III, setae $d 2$ on margin of these incisions, surface without ornamentation. Distance between prodorsal and hysteronotal shields along midline 29 (25-31). Subhumeral setae c3 lanceolate, $12(12-15) \times 2(2-3)$. Opisthosoma gradually attenuate to posterior end; length of interlobar septa 92 (88-94), width of opisthosoma at level of setae h2 33 (33-38). Terminal lamella with three pairs of smooth-edged festoons. Setae $h 2$ whip-like withouth strong enlargement in basal half, greatest width 4 . Setae $h 3$ absent, setae ps 2 greatly reduced. Distance between dorsal setae: c2:d2 48 (45-50), d2: ps1 145 (142-154). Bases of trochanters I, II flanked by narrow sclerotised bands connecting bases of respective epimerites. Coxal setae $4 b$ situated anterior to $3 a$, pseudanal setae ps 3 anterior to coxal setae $4 a$ (Figure $1(\mathrm{~b})$ ). Bases of setae $4 a$ on small sclerites. Pregenital sclerite Y-shaped, connecting inner ends of epimerites IIla and apex of paragenital arch. Length of genital arch 18 (17-23), width 19 (20-26). Distance between ventral setae: $4 b-3 a 15$ (10-15), 3a-g 30 (25-30), 3a-4a 60 (5763), g-ps3 16 (14-17), ps3-ps1 120 (119-127), 4a-4a 81 (78-88). Setae $m G$ of genu I spine-like, straight, with acute apex; seta $m G$ of genu II spine-like with bluntly rounded apex (Figure 3 (b)). Solenidion $\sigma$ of genu III subequal in length to tibia IV. Solenidion $\varphi$ of tibia III about $3 / 4$ of corresponding tarsus, solenidion $\varphi$ of tibia IV about 1.5 times longer than corresponding tarsus. Legs IV 140 (134-152) in length, tarsus IV 29 (29-34) in length.

Female. (Figures 2, 3(e-h) and 4(b-e)); range for 8 paratypes). Idiosomal size, length $\times$ width, $351-371 \times 130-146$. Prodorsal shield as in the male, posterior margin less concave, length $75-82$, width of posterior part 72-78; distance between setae se 78-83. Length of hysterosoma 244-269. Setae c3 lanceolate 9-13. Hysteronotal shield: anterior margin straight, surface with faint reticulate ornamentation, greatest length (from anterior margin to setae h3) 235-244, width of anterior part 55-60 (Figures 2(a) and 4(b)). Setae f2, ps 1 absent; setae $h 1$ anterior to setae e2. Distance between prodorsal and hysteronotal shields along midline 23-41. Opisthosomal lobes moderately developed, terminal cleft as a narrow $U, 31-35$ long. Distance between dorsal setae: $c 2: d 2$ 59-89, d2:e2 93-103, e2:h2 47-52, h2:h3 17-19, h2:h2 53-58, h3:h3 25-34. Supranal concavity ovate, separated from terminal cleft. Coxal fields I, II as in the 


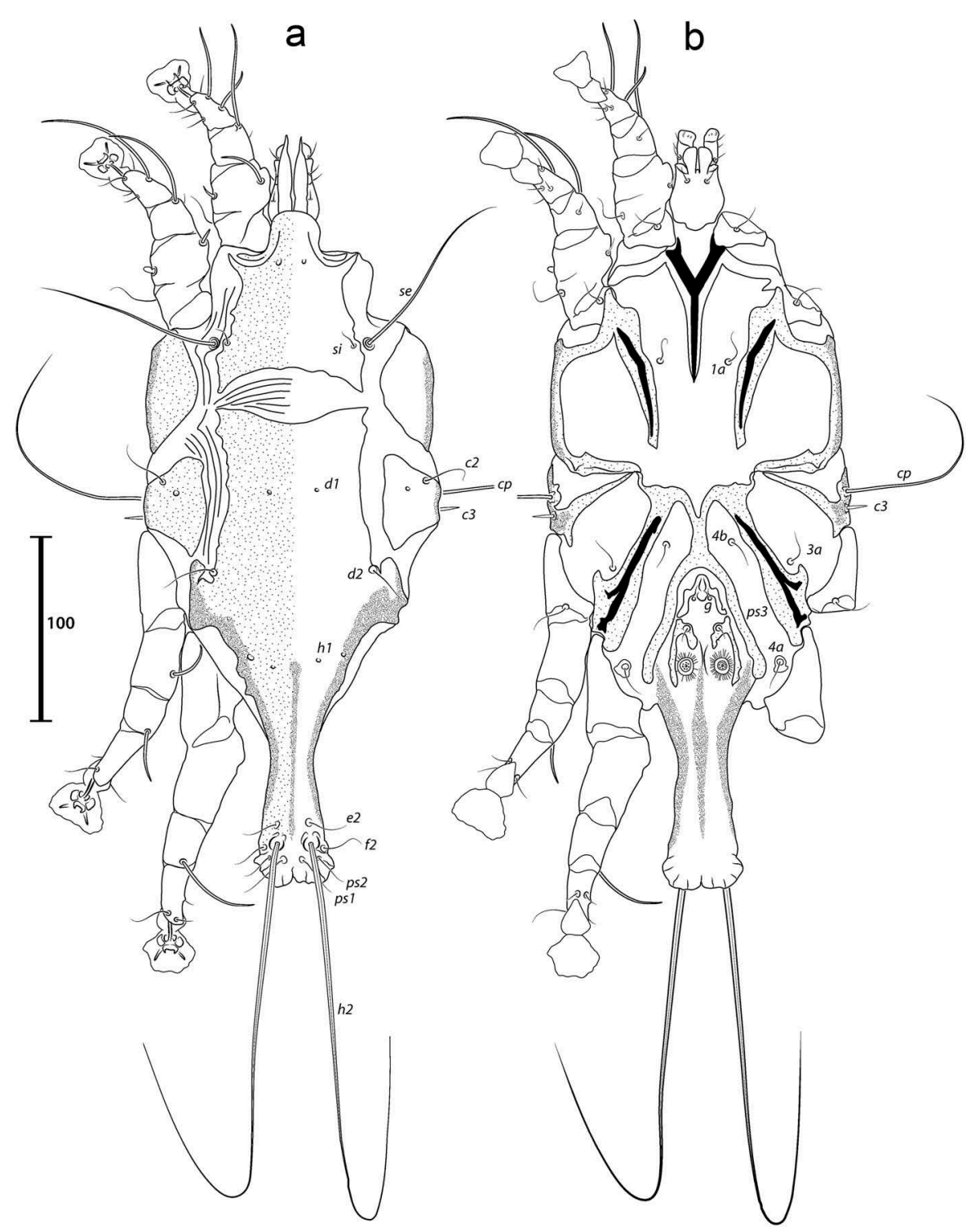

Figure 1. Plicatalloptes atrichogynus sp. nov. (Alloptidae), male: dorsal (a) and ventral (b) views.

male. Epigynium bow-shaped, length $\times$ width, 24-28 $\times$ 51-64 (Figure 2(b)). Legs I, II as in the male. Trochanteral seta sRIII very thin, barely discernible in some specimens. Solenidion $\sigma$ vestigial on genu III (Figure 4(b), detail), solenidion $\varphi$ of tibia III about half the length of tarsus III, solenidion $\varphi$ absent from tibia IV. Tarsi III, IV with small latero-apical crest (Figure 4(d)). Legs IV with ambulacra almost extending to level of setae $h 2$.

\section{Etymology}

The species name is a combination of $a$ (without, G.), tricho (hair, G.), and gynos (female, G.), referring to the vestigial condition of the solenidion $\sigma$ on genua III and the absence of solenidion $\varphi$ from tibiae IV of females.

\section{Differential diagnosis}

The new species, Plicatalloptes atrichogynus sp. nov., is very similar to P. ferrandi (Gaud \& Mouchet, 1957), described from the reed cormorant, Phalacrocorax africanus (Gmelin, 1789). In females of both species, trochanteral seta $s R I I I$ is strongly reduced, solenidion $\varphi$ is vestigial on genu III and solenidion $\varphi$ is absent on tibia IV. These two species can be distinguished by the following characters: in males of $P$. atrichogynus, legs IV with distal half of tarsus surpass the opisthosomal terminus (including terminal lamellae), and in females, the ambulacra of legs IV reach the level of setae $h 2$. In males of $P$. ferrandi, tarsus IV reaches the level of body terminus by ambulacrum, and in females, the ambulacra of legs IV reach the midlevel between supranal concavity and the anterior end of terminal cleft.

Family Proctophyllodidae Trouessart \& Mégnin, 1884 Subfamily Pterodectinae Park \& Atyeo, 1971 Tribe Pterodectini Park \& Atyeo, 1971 Genus Metapterodectes Mironov, 2008

Type species: Metapterodectes furnarius Mironov, 2008, by original designation.

The genus previously included four species: $M$. furnarius Mironov, 2008, M. muticus (Banks 1909), M. leptasthernurae Mironov \& Gonzalez-Acuña, 2011, and M. toxostomae Mironov \& OConnor, 2014, associated with passerines of the families Furnariidae, Emberizidae, and Mimidae (Mironov et al. 2008; Valim and Hernandes 2010; Mironov \& Gonzalez-Acuña 2011; Mironov \& OConnor 2014). A fifth species is described in the following. 


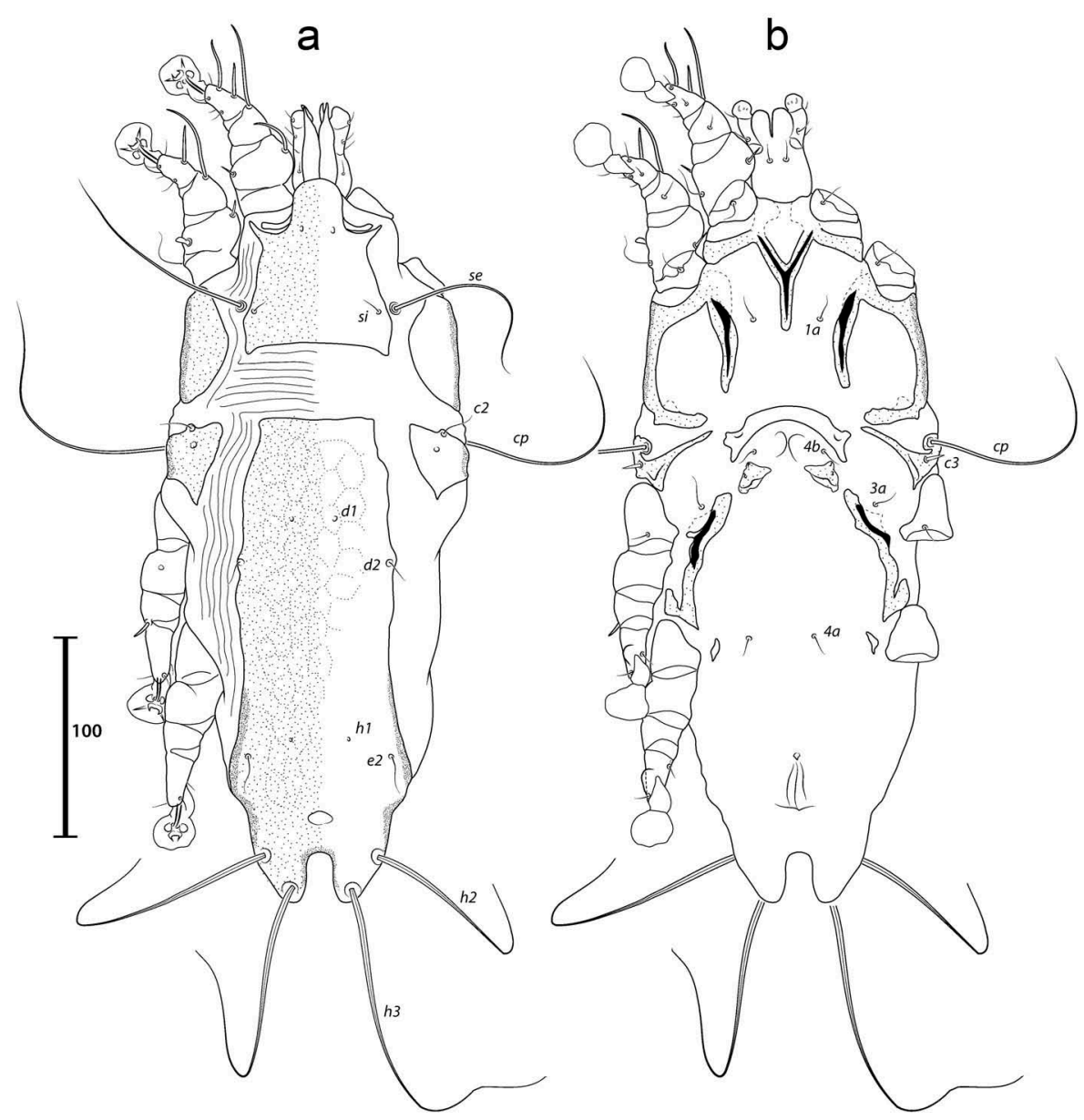

Figure 2. Plicatalloptes atrichogynus sp. nov. (Alloptidae), female: dorsal (a) and ventral (b) views.

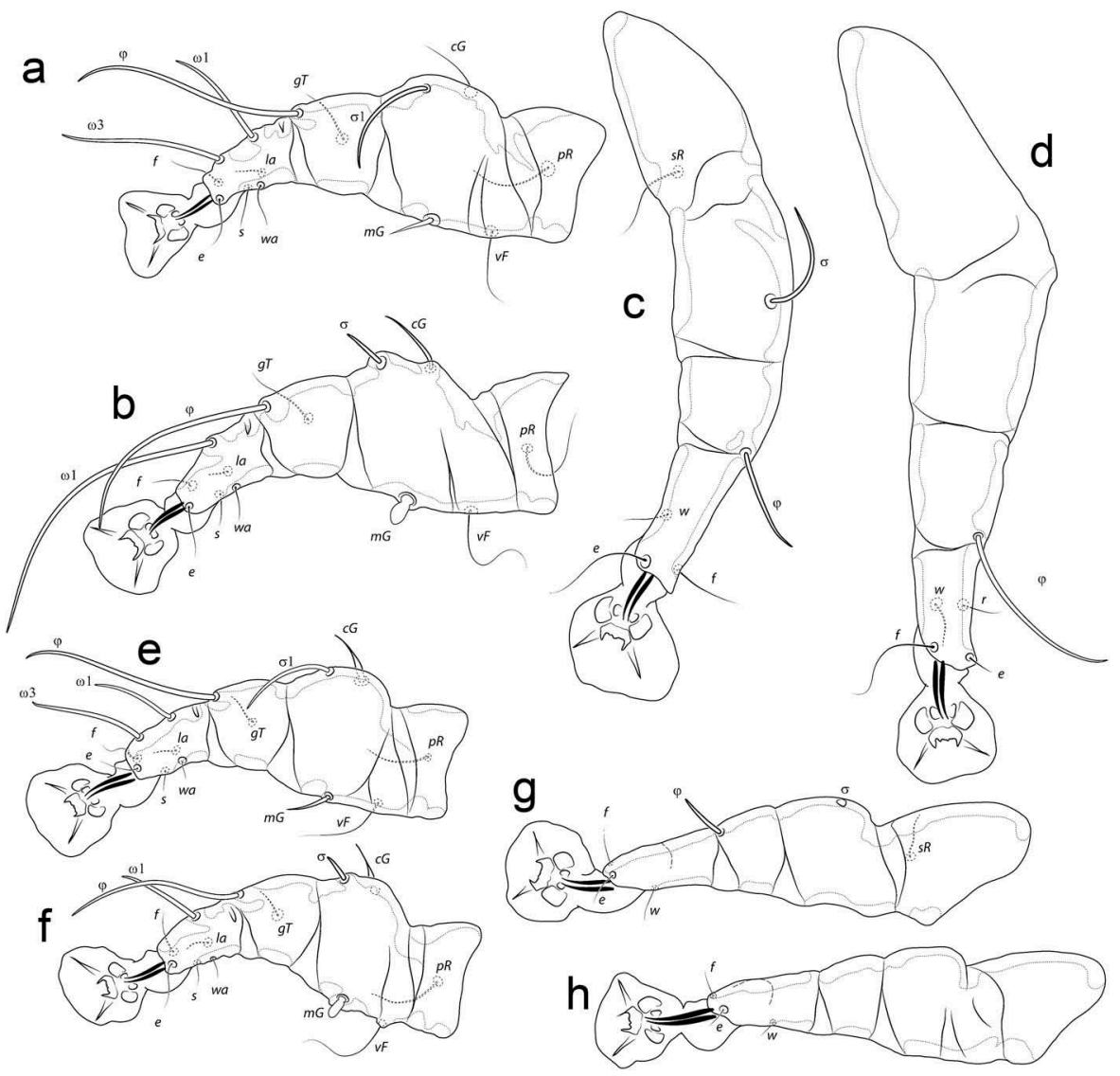

Figure 3. Plicatalloptes atrichogynus sp. nov. (Alloptidae), dorsal view of legs I-IV of male (a-d) and female (e-h). 


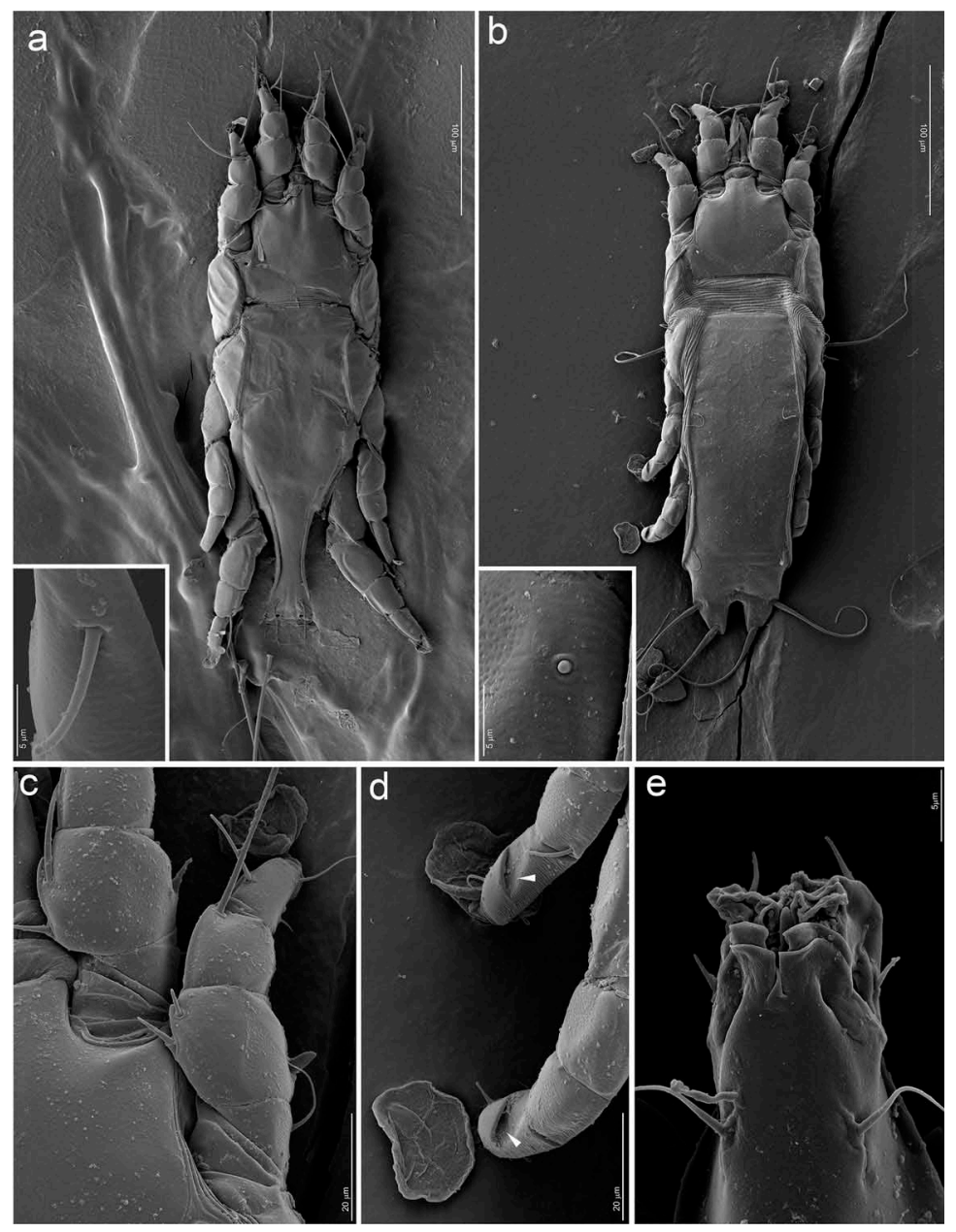

Figure 4. Plicatalloptes atrichogynus sp. nov. (Alloptidae). Low-temperature scanning micrographs: dorsal view of male (a) and female (b), insertions in a and b display normal and vestigial condition of solenidion $\sigma$ of genu III in male and female, respectively; dorsal view of female legs I and II (c); female tibiae and tarsi III, IV with lateral fold on tarsi (d, arrows point to the folds); ventral view of gnathosoma of female (e).

Metapterodectes saturninus Hernandes sp. nov.

(Figures 7-10)

\section{Type material}

Holotype male (DZUNESP-RC \# 3947), paratypes 1 male and 2 females ex Mimus saturninus (Lichtenstein, 1823) (Passeriformes: Mimidae), BRAZIL, São Paulo State, Rio Claro, campus of São Paulo State University (UNESP), $22^{\circ} 24$ S 47 $33^{\prime} \mathrm{W}, 13$ September 2013, F. A. Hernandes col.; paratypes 18 males and 49 females, same host

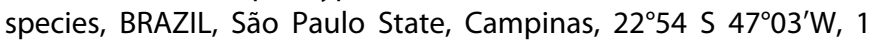
April 2010, David V.Boas-Filho col.

\section{Type deposition}

Holotype male at DZUnesp-RC; paratypes at DZUnesp-RC, DZSJRP, ZISP, UMMZ, USNM, OSAL, MGAB.

Male. (holotype, range for 6 paratypes in parentheses). Idiosoma, length $\times$ width, 411 (392-425) $\times 206$ (165-209). Prodorsal shield: entire, lateral margins slightly concave at level of scapular setae, posterior margin sinuous, posterior angles acute, length 133 (120-136), width 119 (104-125), surface with numerous small circular lacunae (Figure $7(a)$ ); bases of scapular setae se separated by 74 (62-78). Setae ve present, rudimentary. Scapular shields narrow. Humeral shields absent. Setae $c p$ and $c 2$ situated on striated tegument. Subhumeral setae $c 3$ lanceolate $29(26-26) \times 7(7-9)$. Hysteronotal shield: greatest length 253 (242-267), width at anterior margin 112 (99-128), anterior margin concave, surface with numerous small, circular lacunae evenly distributed on the entire surface. Distance between prodorsal and hysteronotal shields 24 (17-31). Posterior margins of opisthosomal lobes rounded. Terminal cleft shaped as an inverted $U$ with divergent branches, 22 (18-23) long. Supranal concavity distinct. Setae $f 2$ anterior to bases of setae $p s 2$. Setae $h 1$ situated slightly anterior to the level of supranal concavity. Setae $h 3$ spiculiform, 24 (24-27) long; setae ps2 100 (91-100) long; setae ps1 filiform, about 6 long, situated slightly anterior to bases of setae $h 3$. Distances between dorsal setae: c1:d2 102 (92-106), d2:h1 100 (99-109), h2:h2 67 (58-69), h3:h3 47 (43-51).

Epimerites I fused into a narrow $\mathrm{U}$, fused part disconnected from epimerites II (Figure 7(b)). Coxal fields I, II without extensively sclerotized areas. Rudimentary sclerites rEplla absent. Coxal fields I-IV open. Epimerites IVa small. Genital arch 40 (38-42) in width; aedeagus 84 (81-86) long from anterior bend to tip, extending to anterior level of anal opening. Genital papillae connected at bases. Genital and adanal shields absent. Adanal suckers 15 (11-17) in diameter, distance between centres of discs 34 (34-42), corolla smooth, surrounding membrane with few radial striae. Opisthoventral shields occupying lateral areas of opisthosoma and distal part of opisthosomal lobes; inner margins of these shields at level of anal suckers with two extensions, anterior extension bearing setae $p s 3$. Setae $4 b$ situated slightly posterior to level of setae $3 a$. Distance between ventral setae: 1a:4b 143 (130-151), 4b:4a 45 (45-51), 4a:g 44 (39-49), g:ps3 57 (54-62), ps3:ps3 83 (77-92).

Femora and other segments of legs I-IV without processes. Solenidion $\sigma 1$ of genu I 10 (9-13) long, situated at midlevel of segment; solenidion $\sigma$ of genu III absent. Genual setae $c G$, II and $m G l$, II filiform. Seta $d$ of tarsi II slightly shorter than corresponding seta $f$; seta $d$ of tarsi III two times shorter than corresponding seta $f$ (Figure $8(\mathrm{c})$ ). Solenidion $\varphi$ of tibia IV extending to anterior level of ambulacral disc. Tarsus IV 38 (38-41) long, without 
claw-like apical process; setae $d$ and $e$ button-like, seta $d$ situated at basal half of segment (Figure 8(d)).

Female (range for 6 paratypes). Idiosoma, length $\times$ width, 522-573 $\times$ 178-232. Prodorsal shield: length $\times$ width, 139-159 × 128-149, surface with few small, circular lacunae, posterior margin with a pair of concavities, bases of setae se separated by 82-91 (Figure 9(a)). Setae ve present, rudimentary. Scapular shields narrow, poorly developed dorsally. Humeral shields absent. Setae $c p$ and $c 2$ situated on striated tegument. Setae c3 lanceolate, 26-31 × 7-9. Anterior and lobar parts of hysteronotal shield separated dorsally by narrow transverse band of soft tegument (Figure 9(b)). Distance between prodorsal and anterior hysteronotal shields 22-48. Anterior hysteronotal shield roughly rectangular, anterior margin concave, greatest length 280-302, width at anterior margin 124-148, surface with numerous small, circular lacunae evenly distributed. Length of lobar region 91-100, greatest width 111-124. Terminal cleft narrow V-shaped, 49-56 long. Supranal concavity distinct; lobar shield entire, surface with few lacunae near anterior margin. Setae $h 1$ inserted at the anterior level of supranal concavity; setae $h 1$ and $f 2$ arranged in a trapezium. Setae $h 2$ lanceolate with apical filament, 71-105 $\times$ 7-8. Setae ps 1 situated near inner margins of opisthosomal lobes, closer to the level of setae $h 3$ than to h2. Setae $h 3$ 16-23 long, about $1 / 8$ of terminal appendages. Distances between dorsal setae: c1:d2 116-131, d2:h1 150-170, h2:h2 87-95, h3:h3 41-53.

Epimerites I fused into a narrow U (Figure 9(b)). Coxal fields I, II open. Epimerites IVa small. Translobar apodemes of opisthosomal lobes present, wide, fused to each other anterior to terminal cleft. Epigynum horseshoe-shaped, greatest width 67-92; apodemes of ovipore not connected to epimerites IIla. Primary spermaduct slightly enlarged near the head of spermatheca; secondary spermaducts 35-41 long (Figure 9(i)). Pseudanal setae $p s 2, p s 3$ button-like, situated at midlevel of anal opening; distance between pseudanal setae: ps2:ps2 38-48, ps3:ps3 36-47, ps2:ps3 6-9.

Femora I, II without crest. Solenidion $\sigma 1$ of genu I short, 11-14 long, situated in distal half of segment. Solenidion $\sigma$ of genu III absent. Genual setae cGIl as in male, $m G$ Il slightly thicker than $m G l$. Seta $d$ of tarsi I, II slightly shorter than corresponding seta $f$, setae $d$ of tarsi III, IV three times shorter than corresponding setae $f$. Genu IV dorsally inflated.

\section{Differential diagnosis}

Metapterodectes saturninus sp. nov. is most similar to $M$. toxostomae Mironov \& OConnor, 2014 described from Toxostoma rufum (Linnaeus, 1758) (Mimidae) in having the dorsal shields covered with numerous small, circular lacunae in both sexes. The new species can be readily distinguished from the latter species by the shape of lobar region of females, having the lateral protrusions bearing setae $f 2$ and $h 2$ more pronounced and almost triangular in shape. Also, lacunae of similar size are evenly distributed on the entire hysteronotal shield in females, and the lobar shield does not have a median incision on the posterior margin. In females of $M$. toxostomae, the lobar region between those setae are rounded and less protruded, lacunae gradually increase in size in the porterior third of the hysteronotal shield, and the lobar shield has a narrow median incision extending to the level of setae $h 1$. In males of both species setae $h 3$ sitting on lobar apices are short and subequal in length $(M$. saturninus 24-27; $M$. toxostomae 25-28), but separated by different distances: in $M$. saturninus, the bases of setae $h 3$ are separated by the distance about twice their length; in $M$. toxostomae, these setae are separated by a distance slightly longer distance than their length.

\section{Etymology}

The specific epithet is taken from the specific name of the type host and is a noun in apposition.

\section{Family Dermoglyphidae Mégnin \& Trouessart, 1884} Genus Neumannella Trouessart, 1907

Type species: Neumannia chelifer Trouessart \& Neumann, 1888, ex Crypturellus cinnamomeus sallaei (Bonaparte, 1856) (Tinamidae), single included species.

As for all dermoglyphids, representatives of the genus Neumannella are syringicoles (i.e. live inside feather quills). The six previously known species of this genus are restricted to birds of the Neotropical family Tinamidae (Tinamiformes): $N$. apodemata Gaud, Atyeo \& Berla, 1973 from Crypturellus soui (Hermann, 1783), N. astacus Dabert \& Skoracki, 2004 from C. tataupa (Temminck, 1815), N. chelifer (Trouessart \& Neumann, 1888) from C. cinnamomeus sallaei (Bonaparte, 1856), N. skorackii Dabert, 2014 from Rhynchotus rufescens (Temminck, 1815), N. tataupai Dabert \& Skoracki, 2004 from C. tataupa, and N. tinamidarum (Berla 1960) from Tinamus solitarius (Vieillot, 1819) (Trouessart and Neumann 1888; Berla 1960; Gaud et al 1973; Dabert \& Skoracki 2004; Dabert 2014). Dabert (2014) provided a key to all previously known species of the genus. The seventh species is described below from Crypturellus parvirostris (Wagler, 1827).

Neumannella crypturella Hernandes sp. nov. (Figures 1-6)

\section{Type material}

Holotype male (DZUNESP-RC \# 3984), paratypes 15 males and 21 females ex Crypturellus parvirostris (Wagler, 1827) (Tinamiformes: Tinamidae) (quills of wing feathers), BRAZIL, Americana, São Paulo State, 5 August 2015, Gustavo Pinto col.

\section{Type deposition}

Holotype male at DZUnesp-RC; paratypes at DZUnesp-RC, DZSJRP, ZISP, UMMZ, USNM, OSAL, MNHN, MGAB.

Male (Figures 1, 2 and 5) (holotype, range for 6 paratypes in parenthesis). Gnathosoma nearly rectangular, relatively small, length 59 (49-56), width 57 (47-55). Idiosoma pear-shaped, gradually attenuating posteriorly, greatest width at the level of sejugal furrow, length $\times$ width $372(361-393) \times 277(242-265)$. Propodosoma and hysterosoma lengths 103 (100-118) and 273 (251-273), respectively. Opisthosoma terminating with two minute pointed angular projections and a small triangular cleft between them. Prodorsal shield narrow, 78 (78-91) in length, width about $1 / 3$ of distance between setae si; central part with two longitudinal adjoining median ridges. Supracoxal seta $s c x$ present. Scapular setae se, si inserted on two separate ovate platelets of prodorsal shield. Setae si only slightly thinner than se, these setae approximately at the same transverse level. Setae si, se, and c2 as macrosetae, about 250 long. Scapular shields absent. Hysteronotal shield roughly ovate with unclear anterior margin, with anterior border crossed by interveining striae; exceed anteriorly the level of setae $d 2$. Surface of prodorsal and hysteronotal shields uniformly doted. Dorsal setae (si, se, c2, d2, $e 2, f 2, h 2, h 3, p s 1)$ simple, long, shaped as long macrosetae. Setae C2 inserted slightly anterior to the level of scapular setae. Hysteronotal gland openings $\mathrm{gl}$ set closer to setae e2 than to d2. Supranal concavity distinct. Distances between bases of dorsal setae and opening: se:se 69 (64-74), c2:c2 153 (137-147), d2:d2 150 (128-141), c2:d2 109 (102-114), d2:gl 73 (70-77), gl:e2 40 (3843), e2:e2 128 (123-132), e2:f2 38 (34-39).

Coxal apodemes (epimerites I, II) with narrow sclerotizations on outer margins. Small median sclerotized plate encompasses inner tips of apodemes III and IIIa making coxal fields III closed. Coxal fields IV and lateral half of coxal fields III strongly sclerotized. Genital papillae set on small roughly triangular pregenital apodeme, much closer to setae $4 b$ than to $g$, setae $4 b$ set on striated 


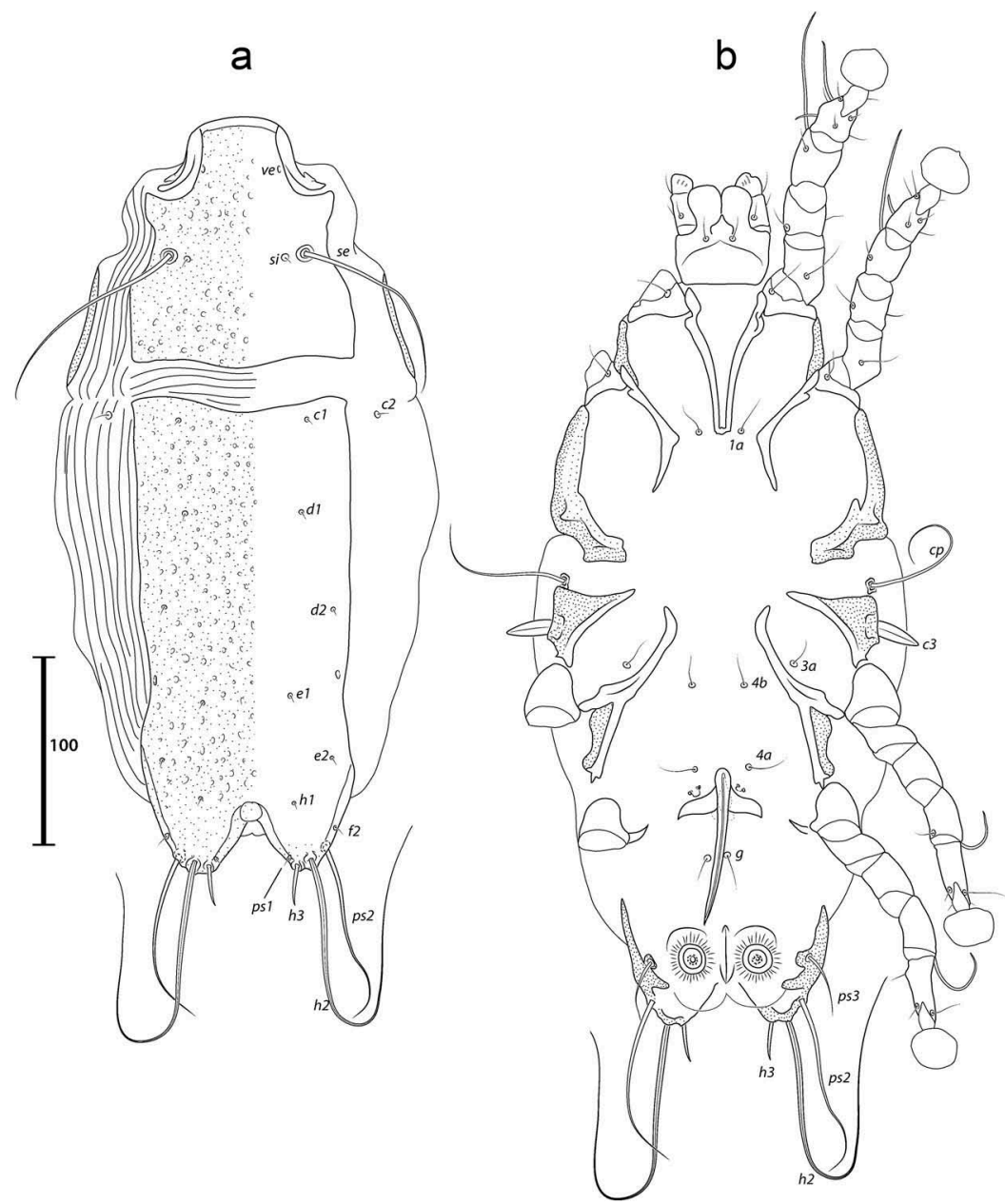

Figure 5. Metapterodectes saturninus sp. nov. (Proctophyllodidae), male: dorsal (a) and ventral (b) views.

tegument. Adanal suckers shaped as an inverted teardrop, 21 (16-20) in length, 13 (9-13) in width. Tibiae I, II and III with small apico-ventral spines. Legs III thinner but twice longer than two pairs of anterior legs, reaching body terminus with ambulacra, and extending to the basal end of tarsi IV. Tarsi III with apico-dorsal spine. Legs III, IV more darkly sclerotized than anterior legs, legs IV strongly hypertrophied. Complex tibia-tarsus IV modified into big pincers. Tibia IV with large rounded apico-ventral apophysis. Tarsus IV with rounded apex, ambulacra IV absent. Setae $d$ and $e$ of legs IV shaped as microsetae (Figure 10(d)).

Solenidion $\sigma$ of genu III about the same length of corresponding tarsus (excluding ambulacrum and ambulacral stalk). Solenidion $\varphi$ of tibia III about as long as corresponding tarsus (including ambulacrum). Solenidion $\varphi$ of tibia IV about as long as corresponding tibia.

Female (Figures 3, 4 and 6) (range for 7 paratypes). Gnathosoma nearly rectangular, length $46-56$, width $47-55$. Idiosoma elongated with rounded terminus, length 373-396, width 135-210. Propodosoma and hysterosoma lengths 116-140 and 251-268, respectively. Prodorsal shield as in the male, narrow, 95-109 in length, as wide as $1 / 3$ of distance between setae si. Supracoxal seta $s c x$ presente. Setae si piliform, about 10 long, inserted on small oval plates along with setae se. Hysteronotal shield absent, entire dorsum of hysterosoma striated. All dorsal idiosomal setae piliform. Setae c2 about twice as long as $d 2$. Hysteronotal gland openings $\mathrm{gl}$ much closer to level of setae $e 2$ than to $d 2$. Distances between bases of dorsal setae and openings: se:se 61-73, c2:c2 126-170, d2:d2 89-103, c2:d2 111-122, d2:gl 85-95, gl:gl 117-65, h2:h2 69-79.

Coxal apodemes (epimerites) I, II as in the male. Epigynum absent. Setae $3 a, g$ and genital papillae approximately at the same transverse level. Setae $4 a$ at level of trochanters III, setae $p s 3$ at anterior level of anal opening. Tibiae I-IV with small apico-ventral spines. Solenidion $\sigma$ of genu III about the same length of corresponding tibia. Solenidion $\varphi$ of tibia III about 1.5 times the length of corresponding tibia. Solenidion $\varphi$ of tibia IV only slightly longer than corresponding tibia.

\section{Differential diagnosis}

The new species, Neumannella crypturella sp. nov., is most similar to N. astacus Dabert \& Skoracki, 2004 in having in both sexes a narrow prodorsal shield (with maximum width at midlevel about $1 / 3$ the distance between setae si), in males the opisthosoma ending with two small spines, and in females in lacking the hysterosomal shield. The new species can be distinguished from $N$. astacus by the following features: in males, the corolla of anal suckers has an acute posterior extension, the pregenital apodeme does not encompass the bases of setae $4 b$; and in females, setae se are much shorter and reach only the halfway to the gland openings $\mathrm{gl}$. In males of $\mathrm{N}$. astacus, the corolla of anal suckers is circular and the pregenital apodeme encompasses the bases of setae $4 b$, and in females, setae se extend beyond the level of the gland openings $\mathrm{gl}$.

\section{Etymology}

The new species name is derived from the generic name of the type host, feminine, and is a noun in apposition.

Superfamily Pterolichoidea Trouessart \& Mégnin, 1884

Family Vexillariidae Gaud \& Mouchet, 1959

Subfamily Vexillariinae Gaud \& Mouchet, 1959

Genus Oustaletia Trouessart, 1885 (as a subgenus of Pterolichus)

Type species: Pterolichus (Oustaletia) pegasus Trouessart, 1885, by monotypy. 


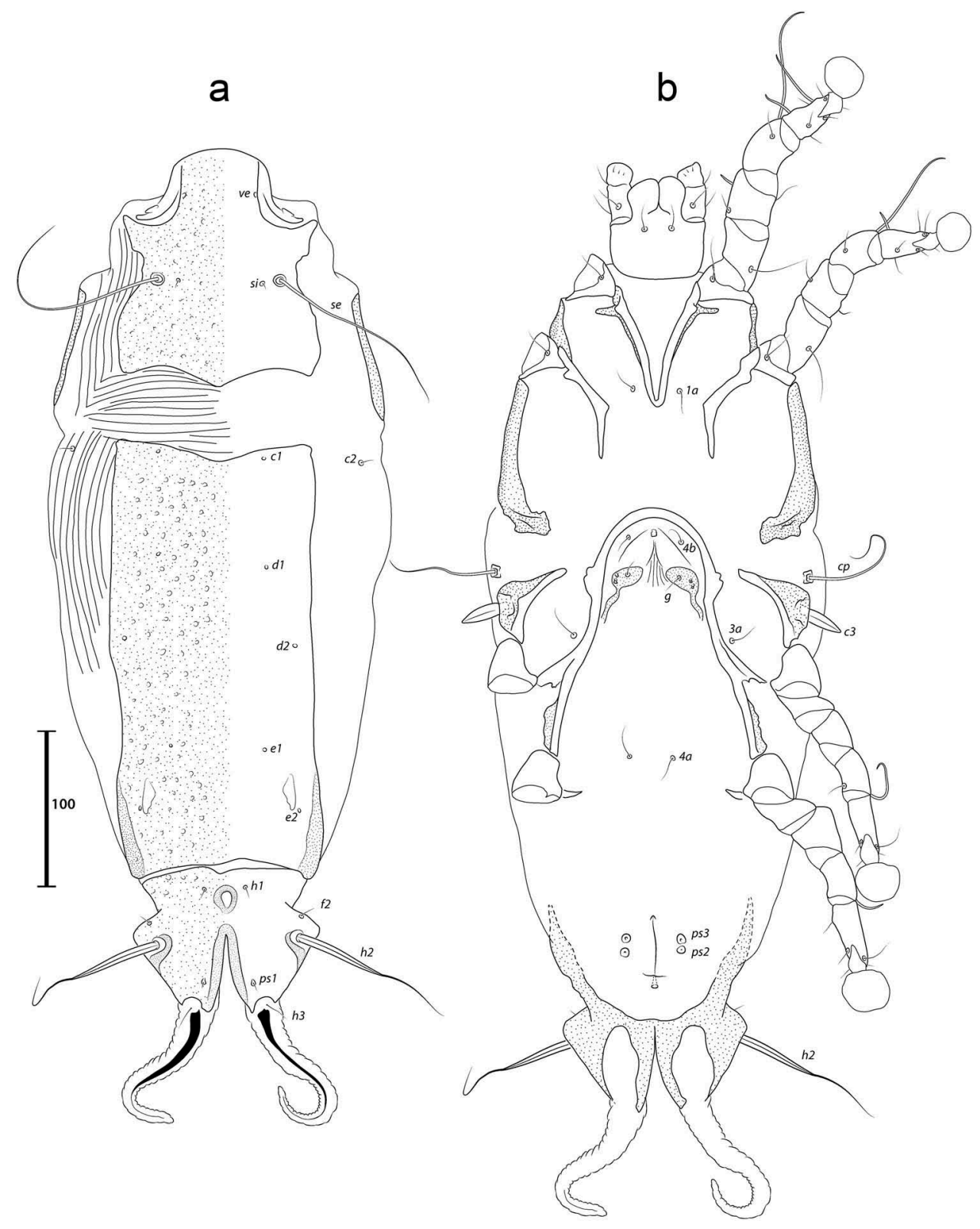

Figure 6. Metapterodectes saturninus sp. nov. (Proctophyllodidae), female: dorsal (a) and ventral (b) views.

Oustaletia pegasus Trouessart, 1885 (Figures 7-13)

Type material examined

Syntypes: 2 males ex Anorrhinus galeritus (Temminck, 1831) (Bucerotidae), MALAYSIA, Malacca, P. Mayer col. (MNHN \# 969.678.1, 969.678.2, slides 33114, 33I15).

\section{Additional material examined}

1 male and female ex Anorrhinus galeritus galeritus (Temminck, 1831) (Bucerotidae), BORNEO, Sabah, Little Kretam River, Kinbatangan District, 18 May 1950 (FMNH \# 211792); 3 males and 3 females from the same host, Malacca, Malaysia, 10 August 1875 Beel \& Steere col. (UMMZ \# 23398, 23399).

This remarkable mite is the sole species of the genus Outaletia, a taxon originally created by Trouessart as a subgenus of Pterolichus Robin, 1868, but soon after elevated to the full generic status (Trouessart 1885a, 1885b). Trouessart (1884a, 69) also described another variety (subspecies), Pterolichus (Oustaletia) pegasus retusus Trouessart, from Anthracoceros albirostris (Shaw, 1808) [=Hydrocissa albirostris] from North India and Anorrhinus galeritus from Malacca (Malaysia), distinguished from the type species by having setae $c 2$ with anterior margin bluntly rounded rather than pointed anteriorly. This latter form was apparently the one figured in the monograph on feather mites of the world (Gaud and Atyeo 1996, Fig. 243).

\section{Hosts}

Several hornbills (Bucerotidae) were originally cited as hosts of Oustaletia p. pegasus by Trouessart (1884): Anorrhinus galeritus (Temminck), Rhyticeros plicatus (Foster), Buceros hydrocorax Linnaeus [=Hydrocorax planicornis] from Asia (Malaysia, Philippines, and New Guinea). By using "etc." after the third host, Trouessart certainly meant findings of this species on more hosts. In the collections of the MNHN, slides from the following hornbills were found to contain this mite species: Rhyticeros undulatus (Shaw) from Java, Anthracoceros albirostris (Shaw, 1808) from North India, Anthracoceros albirostris convexus (Temminck) from Sumatra, Bucorvus leadbeateri (Vigors) (=Bucorvus cafer) from South Africa, Penelopides manillae (Boddaert) from Philippines. Also, one additional slide with this mite from the red-tailed black cockatoo Calyptorhynchus banksii macrorhynchus Gould (Psittaciformes: Cacatuidae) from Australia is present at MNHN; finding on this host is obviously result of accidental contamination. 


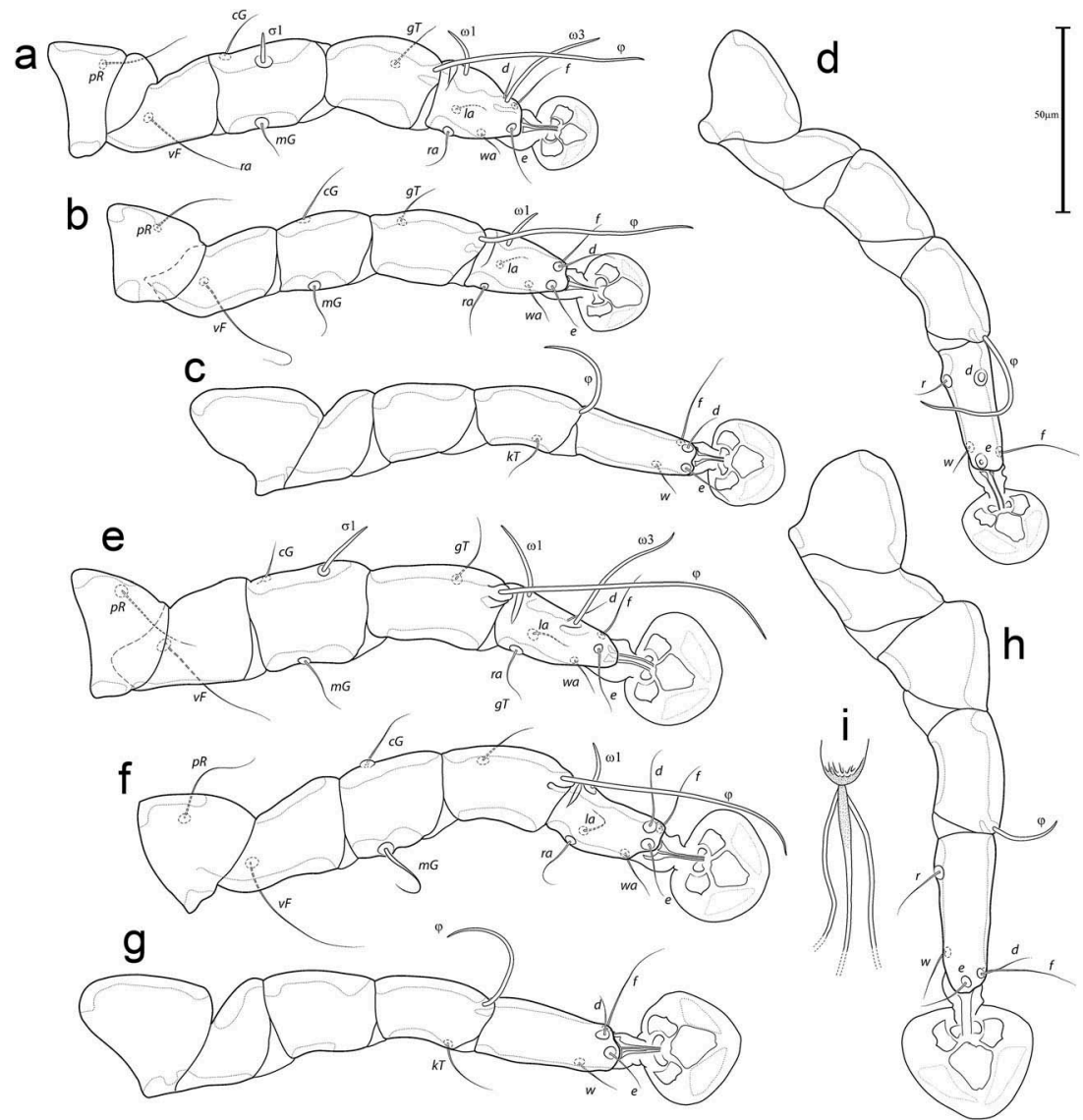

Figure 7. Metapterodectes saturninus sp. nov. (Proctophyllodidae): dorsal view of male (a-d) and female (e-h) legs I-IV, and female spermatheca (i).
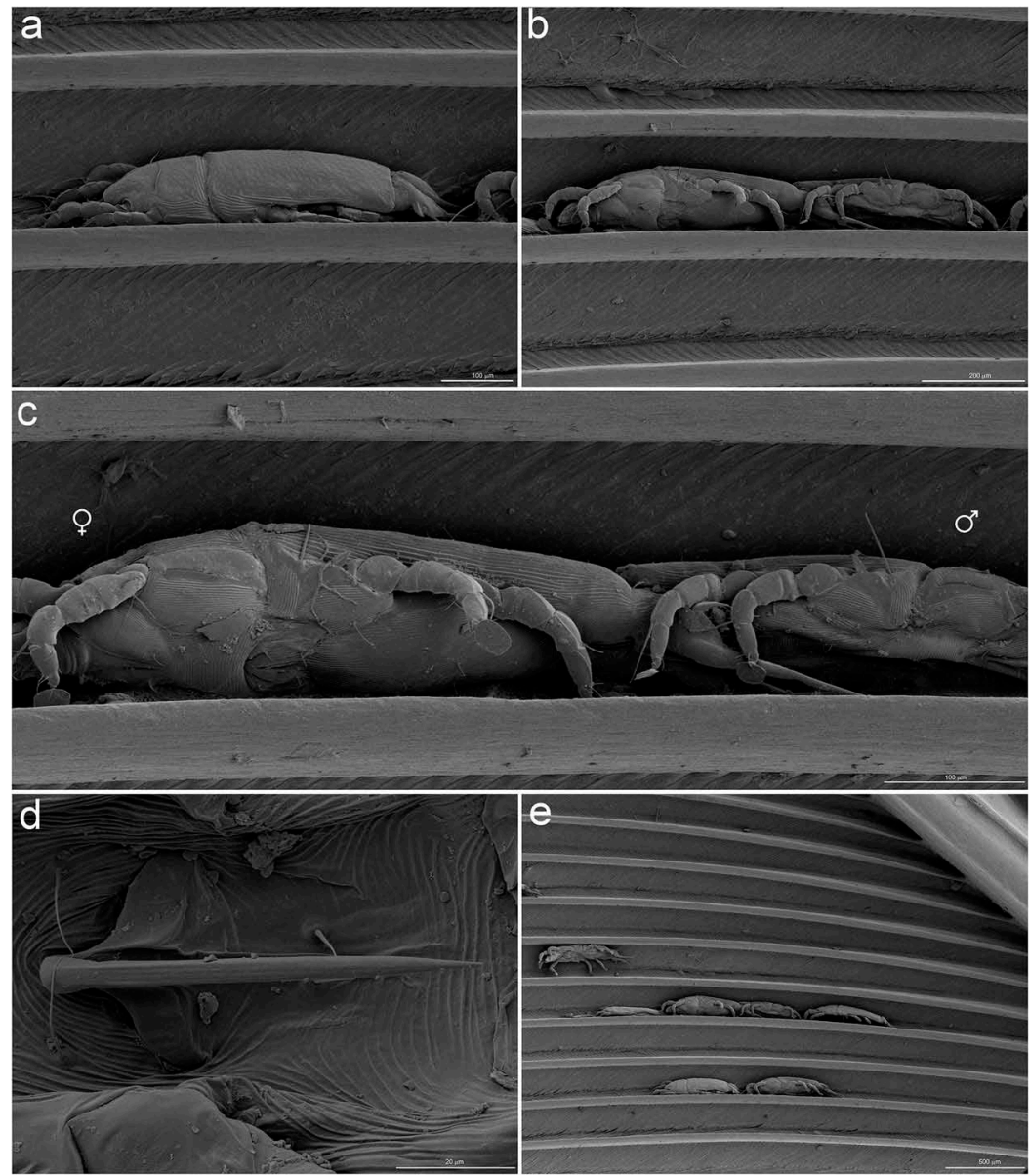

Figure 8. Metapterodectes saturninus sp. nov. (Proctophyllodidae). Low-temperature scanning micrographs: lateral view of female (a), mating couple (b, c), ventral view of male aedeagus (d), and specimens on the ventral surface of flight feather (e). 


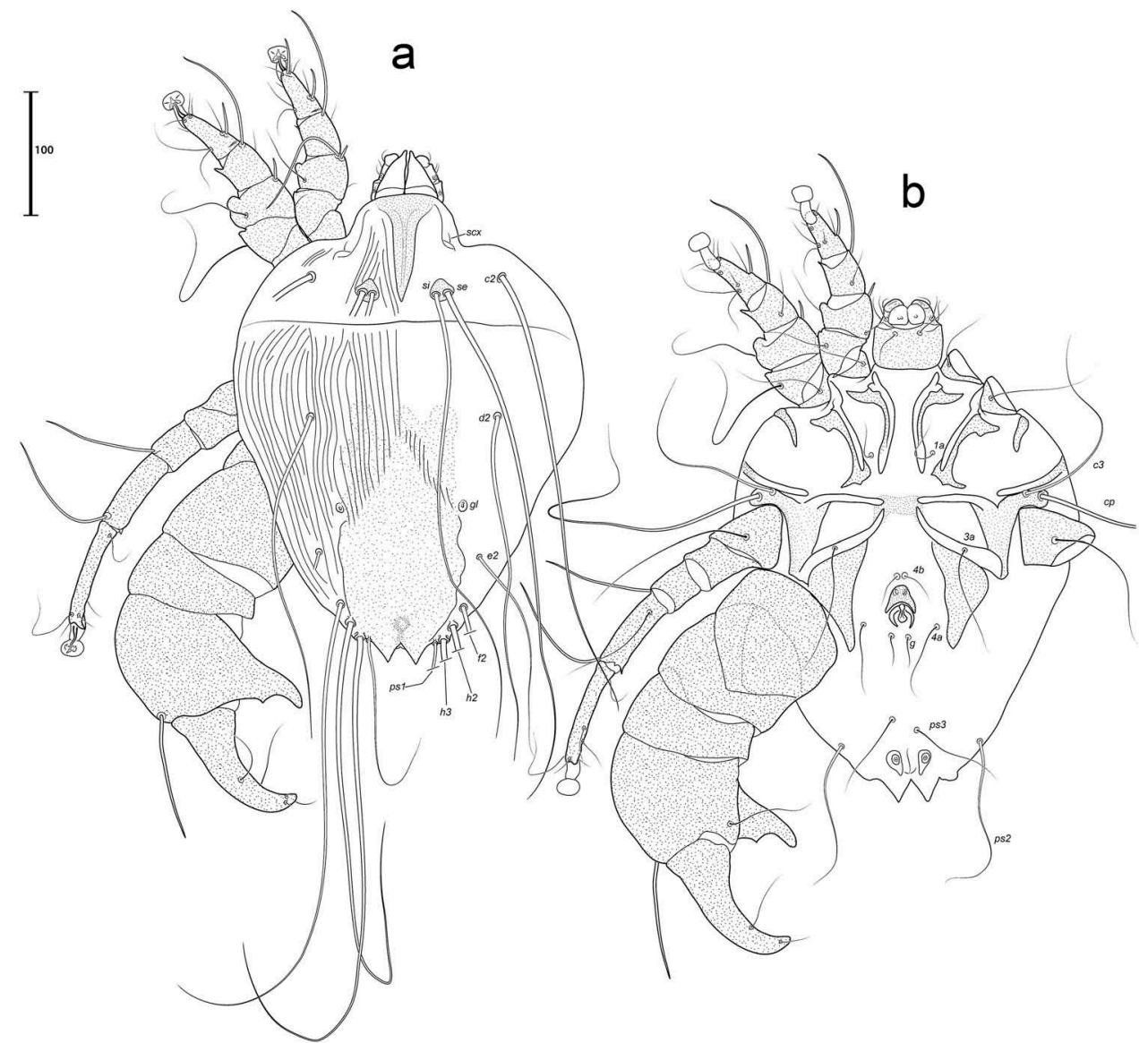

Figure 9. Neumannella crypturella sp. nov. (Dermoglyphidae), male: dorsal (a) and ventral (b) views.

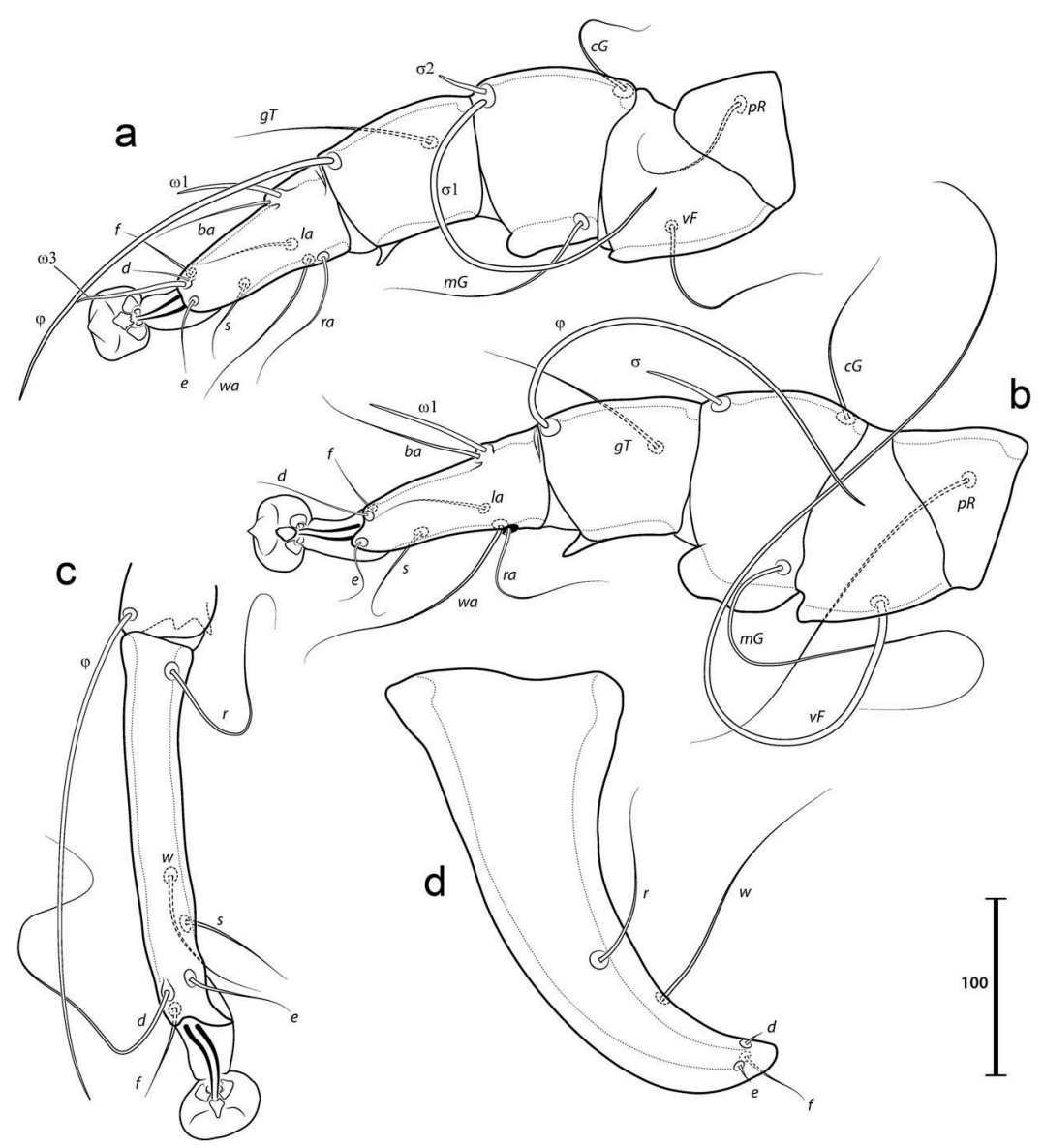

Figure 10. Neumannella crypturella sp. nov. (Dermoglyphidae), dorsal view of male legs I, II (a, b), tarsus III and IV (c, d). 


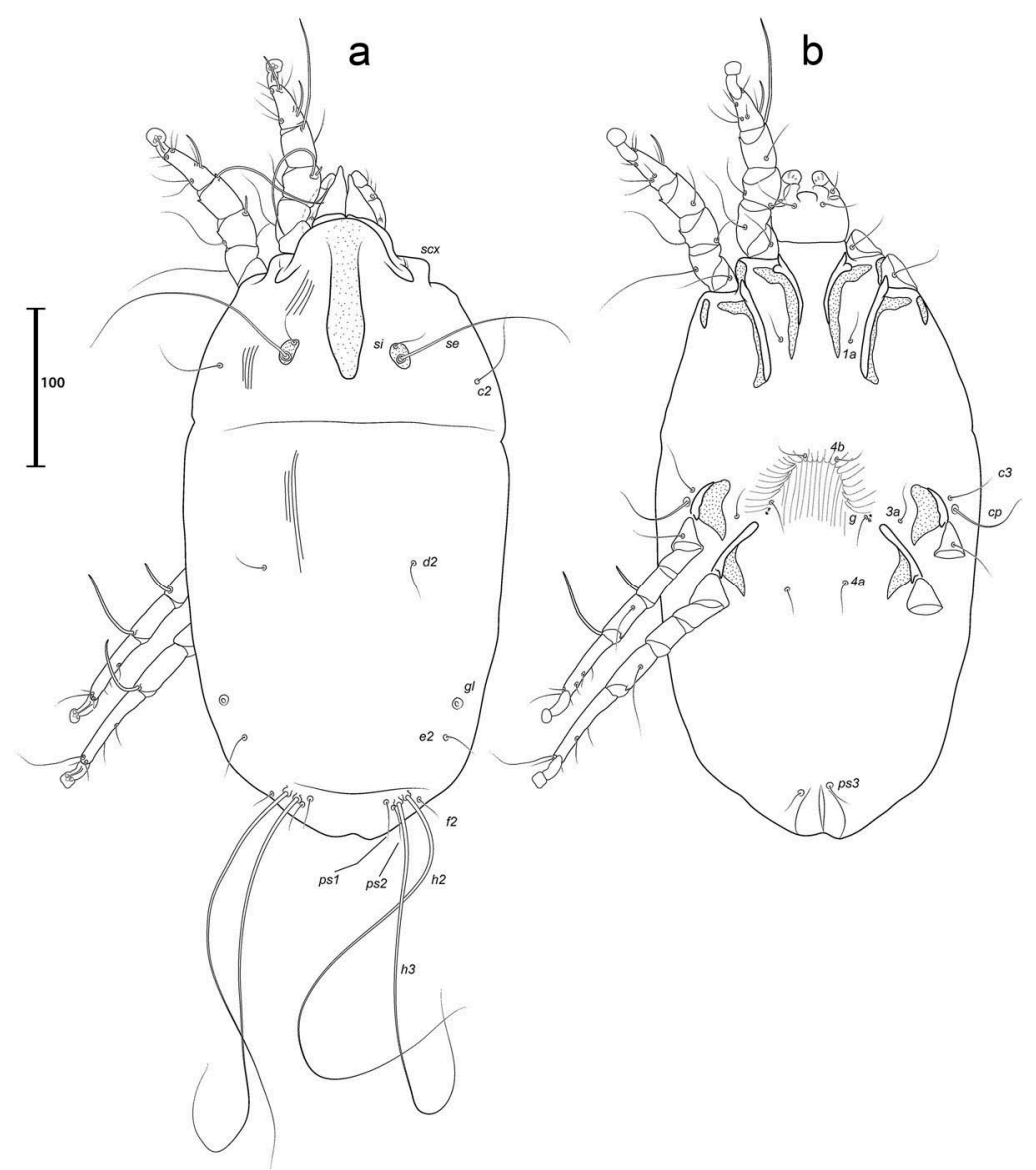

Figure 11. Neumannella crypturella sp. nov. (Dermoglyphidae), female: dorsal (a) and ventral (b) views.

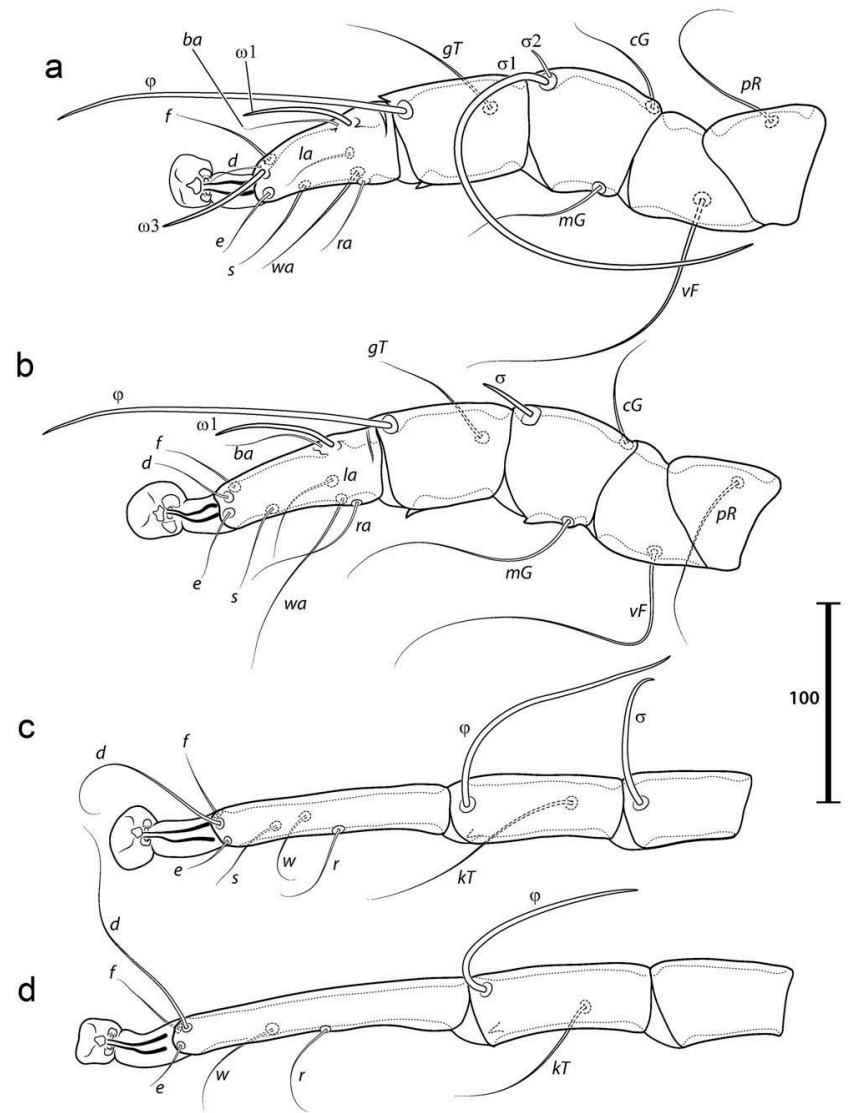

Figure 12. Neumannella crypturella sp. nov. (Dermoglyphidae), dorsal view of female legs I, II (a, b), genua, tibiae and tarsus III, IV (c, d). 

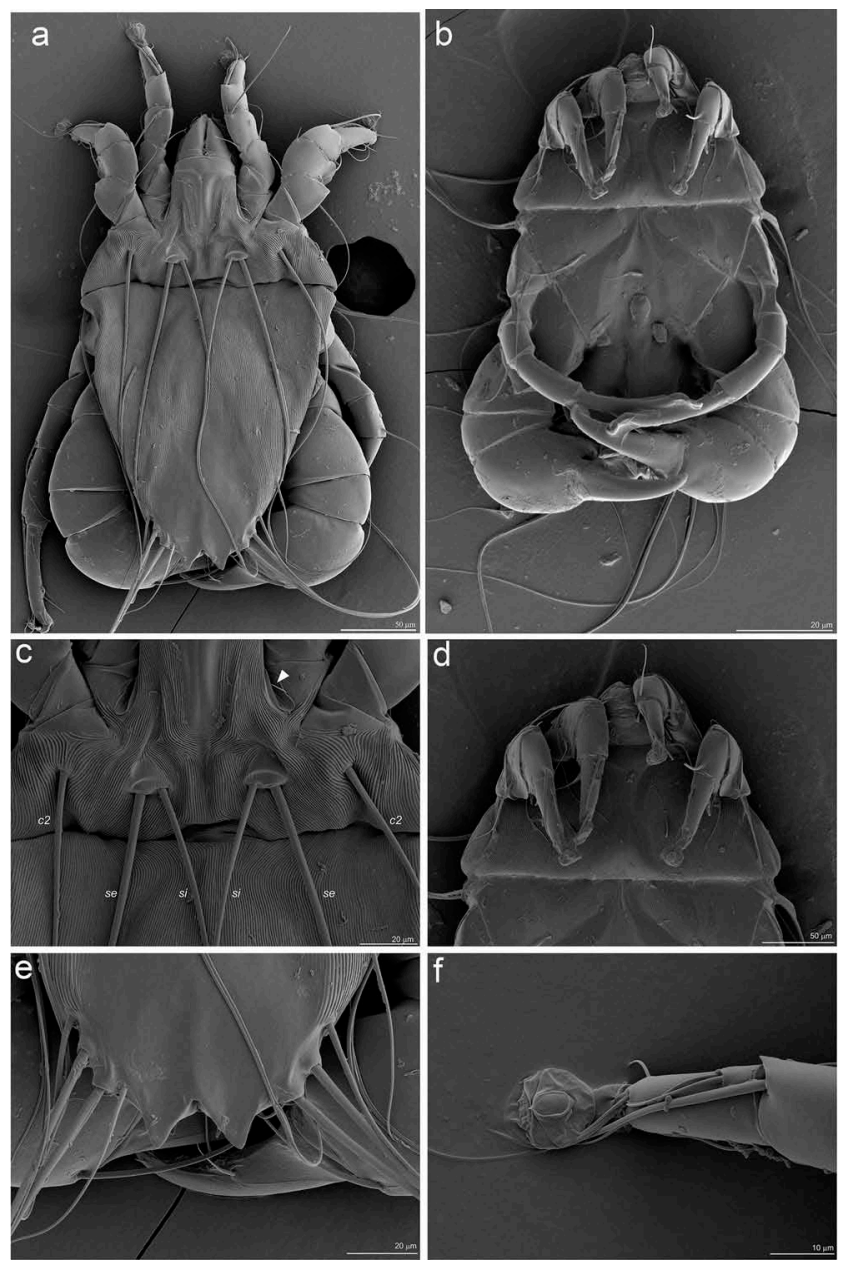

Figure 13. Neumannella crypturella sp. nov. (Dermoglyphidae), male. Low-temperature scanning micrographs: dorsal (a) and ventral (b) views; sejugal region dorsal $(c$; arrow points to the supracoxal seta $s c x)$; propodosoma ventral (d); opisthosomal terminus dorsal (e); tarsus I (f).

\section{Remarks}

Males of this species have unique morphological features. The propodosoma is anteriorly expanded towards the base of chelicerae, in a concave C-shaped structure (Figure 11(b)). Setae $h 3$ are greatly expanded and flattened, in a smooth-edge leaf-like structure with the largest setal area in relation to the body of all known feather mites (Figures 7(a) and 11(a)); other setae are branched (e1), leaf-like with expansions ( $c 2)$, spiky $(h 1, p s 1)$ or sword-like $(c p)$. The females also have large sword-like setae $c 2$ and $c p$, and the opisthosomal terminus is adorned with numerous small, rounded, bullet-like protrusions posterior to setae $p s 1, h 3$, and $h 2$ (Figure 13(f)). In both sexes, ambulacra are distally bilobed (Figure 12(d)). All tarsal setae are positioned distally in the segment, and like in other members of the Vexillariidae, genual solenidia are absent from tibia III, and only one ventral setae is present on tarsus III.

Family Pterolichidae Trouessart \& Mégnin, 1884 Subfamily Pterolichinae Trouessart \& Mégnin, 1884 Genus Opisthocomacarus Dubinin, 1955

Type species: Pterolichus (P.) umbellifer Trouessart, 1899, by original designation.

Opisthocomacarus umbellifer (Trouessart, 1899)

(Figures 13 and 14)

\section{Type material examined}

Syntypes 5 males and 7 females, ex Opisthocomus hoazin (Müller, 1776) (Opisthocomiformes: Opisthocomidae), GUYANA, no further data (MNHN-Ac969.900, slide number 35G9).

\section{Additional material examined}

13 males and 16 females from O. hoazin, BRAZIL, Pará State, Fazenda Fartura, $09^{\circ} 40^{\prime} \mathrm{S} / 50^{\circ} 23^{\prime} \mathrm{W}$, Santana do Araguaia, 08 September

2013, D.V. Boas-Filho coll. (\#1112).

\section{Remarks}

This species bearing idiosomal setae of quite amazing structure (Figures 13 and 14) was redescribed by Dubinin (1955), Atyeo and Gaud (1971), and most recently by Hernandes and Mironov (2015). The latter authors have hypothesized that the flattened and spiky setae might hold a film of water around the mite preventing it from drowning when the nestlings of hoatzins accidentally fall or throw themselves into the water in order to escape from predators.

\section{Discussion}

The LT-SEM technique produces mites that are frozen in prestine condition as if they were still alive without the use of chemical treatments or critical point drying. In addition, the attachment of the cryo-preparation chamber to a field emission SEM provides high-resolution images of specimens with high magnification. Therefore, a more comprehensive interpretation of the morphology can be obtained. In the feather mites studied herein, it was possible to visualize the vestigial solenidion $\sigma$ on genu III of Plicatalloptes atrichogynus sp. nov. females (Figure 4(b), detail), and the complete absence of solenidion $\varphi$ on tibia IV. Such minute structures are extremely difficult to visualize with light optical microscopy, or at least their interpretation concerning their vestigial status or absence would be highly doubtful without the use of LT-SEM. It 

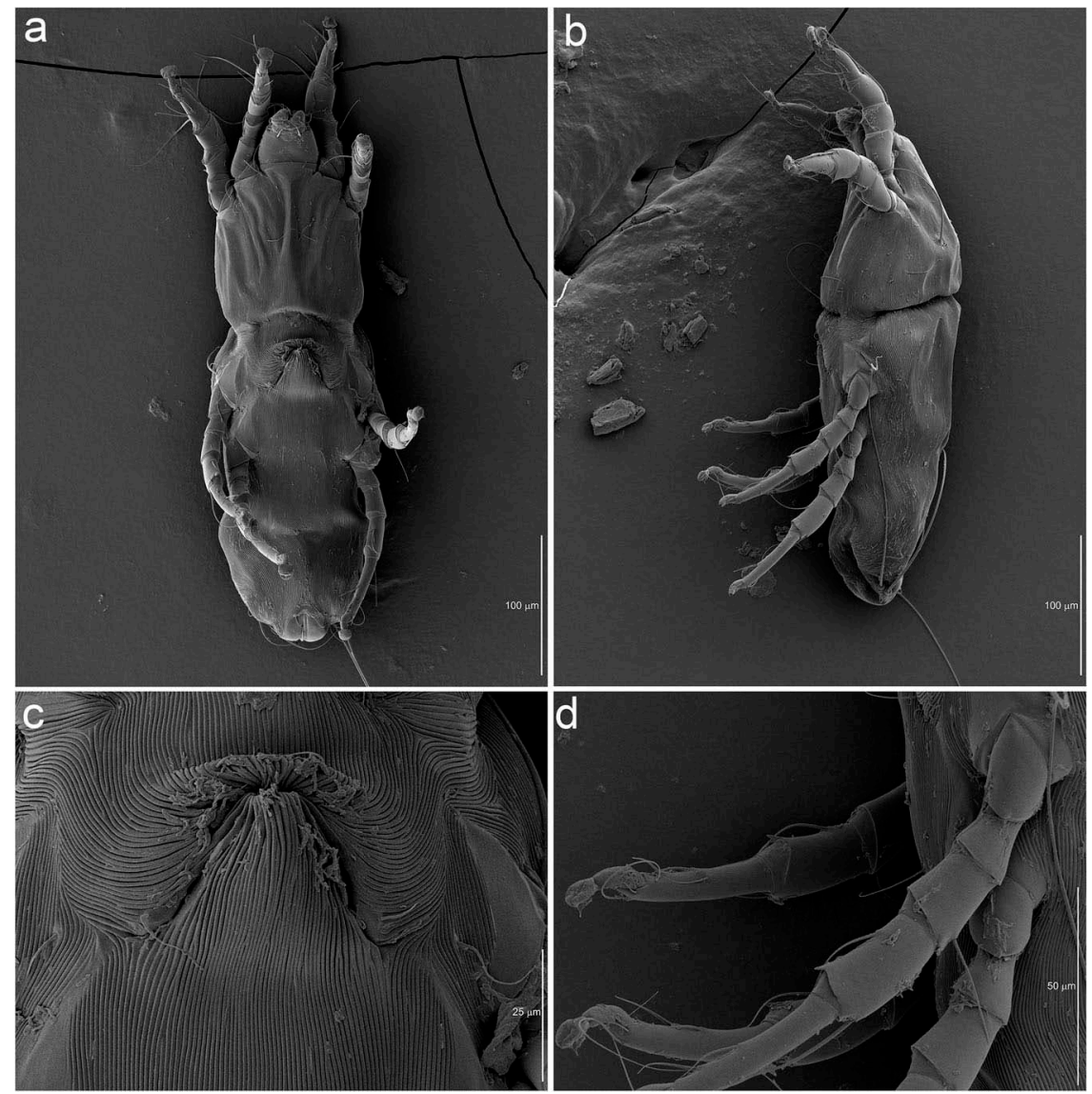

Figure 14. Neumannella crypturella sp. nov. (Dermoglyphidae), female. Low-temperature scanning micrographs: ventral (a) and lateral (b) views; oviporus (c); lateral view of opisthosoma and posterior legs (d).

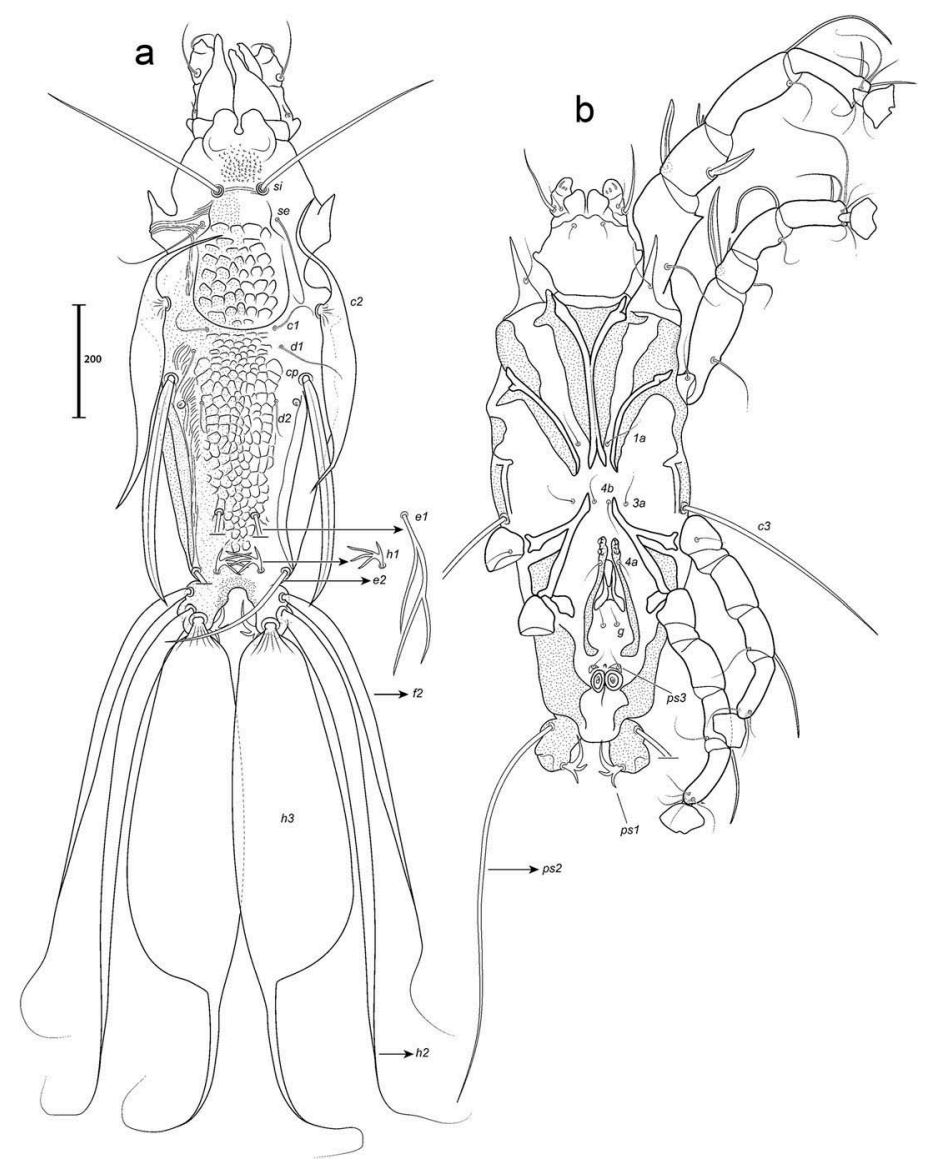

Figure 15. Oustaletia pegasus Trouessart, 1884 (Vexillariidae), male: dorsal (a) and ventral (b) views. 


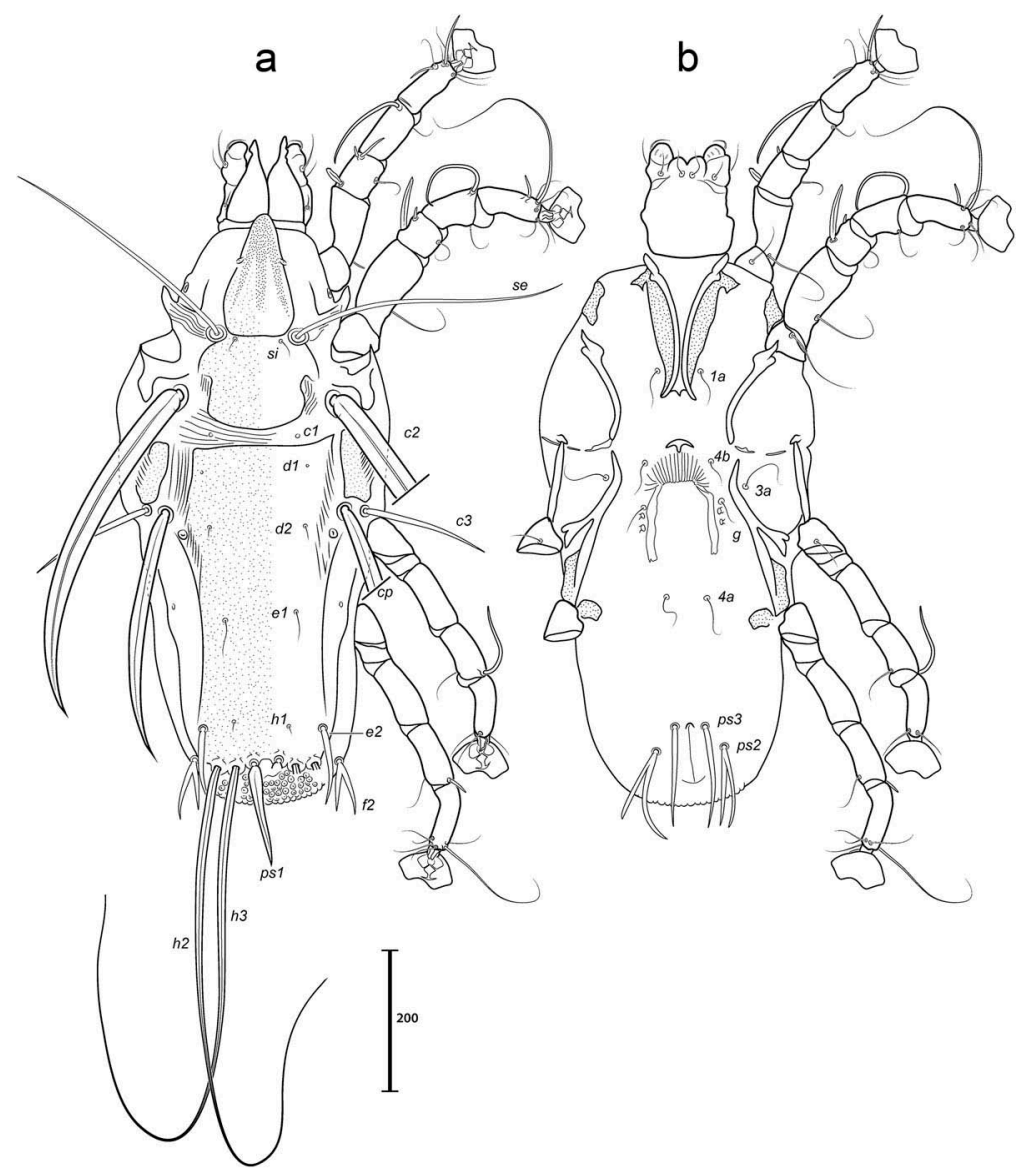

Figure 16. Oustaletia pegasus Trouessart, 1884 (Vexillariidae), female: dorsal (a) and ventral (b) views.

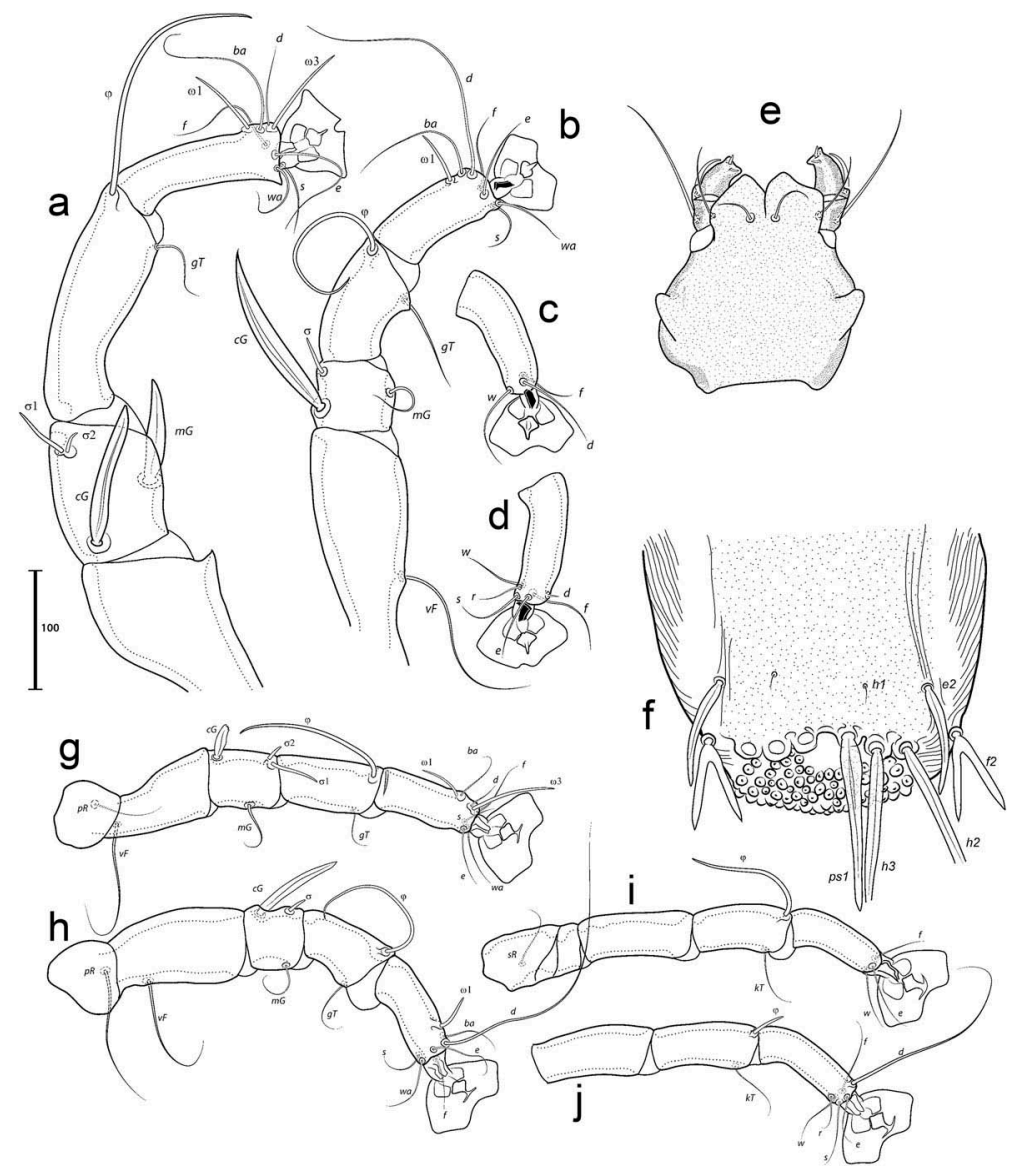

Figure 17. Oustaletia pegasus Trouessart, 1884 (Vexillariidae): dorsal view of distal part of femur, tibia and tarsus of leg I and II (a, b), tarsus III, IV (c, d), ventral view of gnathosoma of male (e), dorsal view of female opisthosoma ( $f$ ), and female legs I-IV (g-j). 


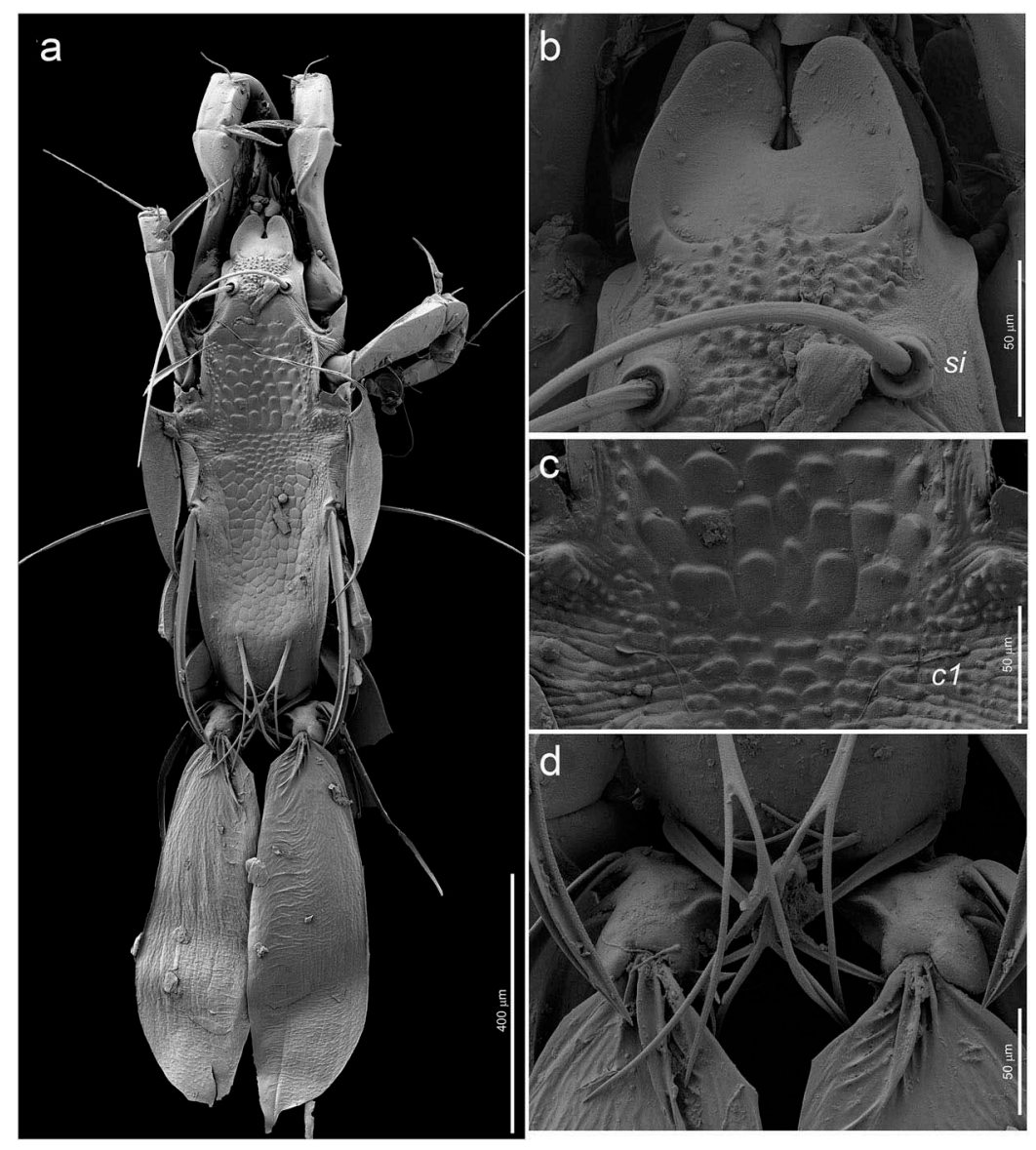

Figure 18. Oustaletia pegasus Trouessart, 1884 (Vexillariidae), male. Low-temperature scanning micrographs: dorsal habitus prodorsal extension of gnathosomal tectum (b); central region of prorsal shield (c); opisthosomal lobes (d).
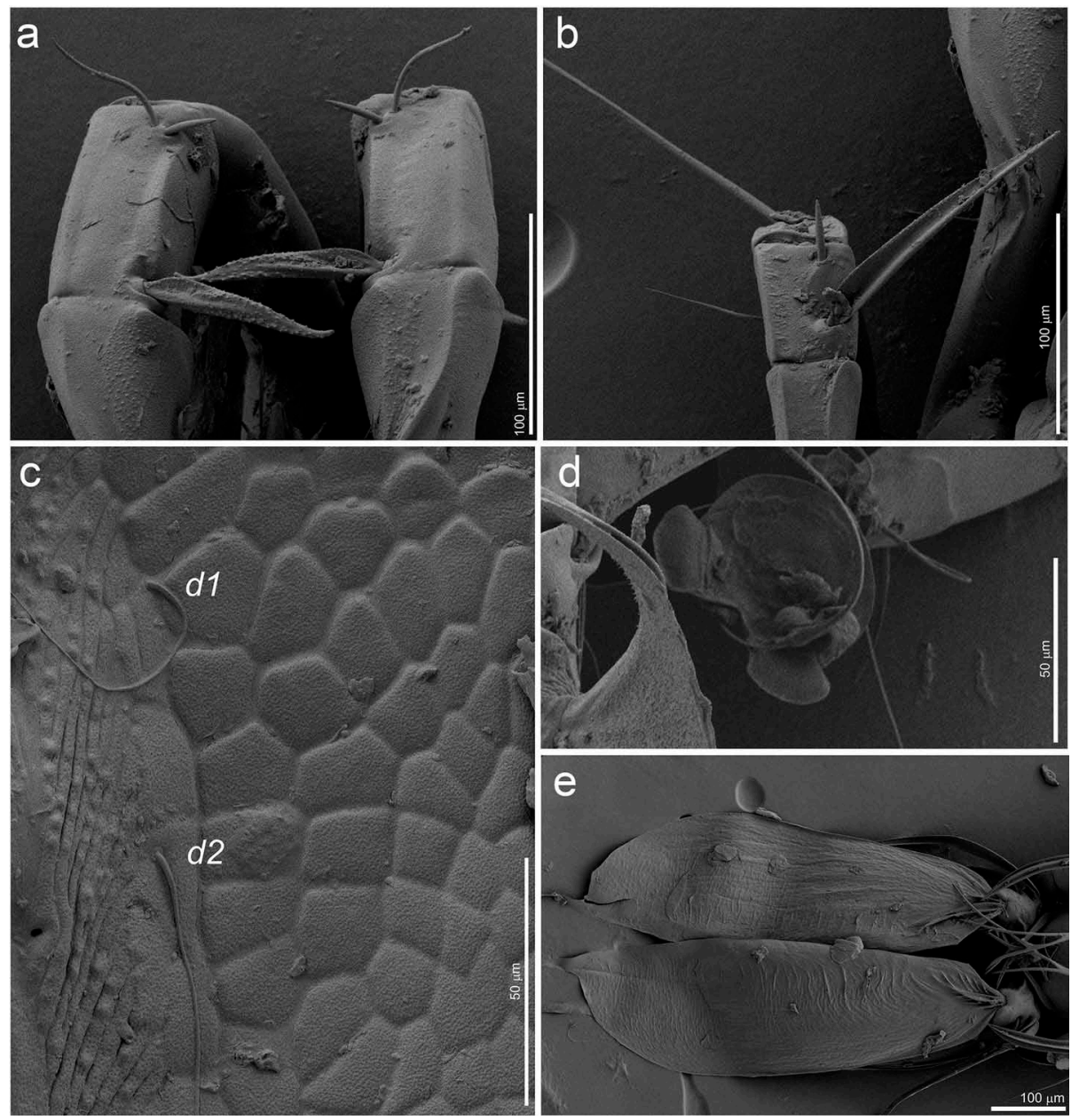

Figure 19. Oustaletia pegasus Trouessart, 1884 (Vexillariidae), male. Low temperature scanning micrographs: genua of legs I (a); genu II (b); dorsal hysterosoma around setae $d 1$ and $e 1$ (c); ambulacrum of leg II (d); setae $h 3$ (e). 

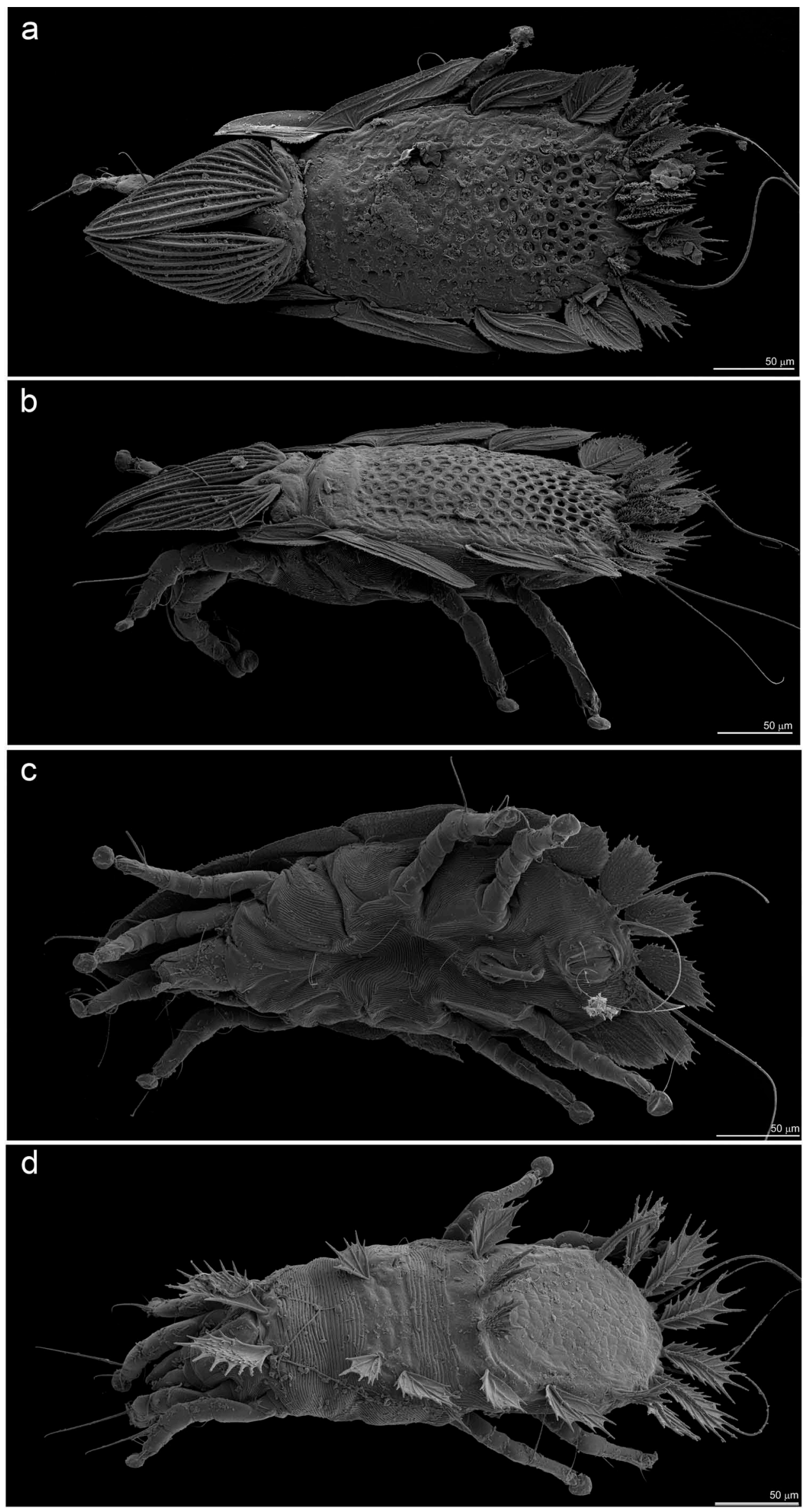

Figure 20. Opisthocomacarus umbellifer (Trouessart, 1899) (Pterolichidae). Low-temperature scanning micrographs: dorsal (a) and lateral (b) views of female; ventral view of male (c); dorsal view of tritonymph (d). 

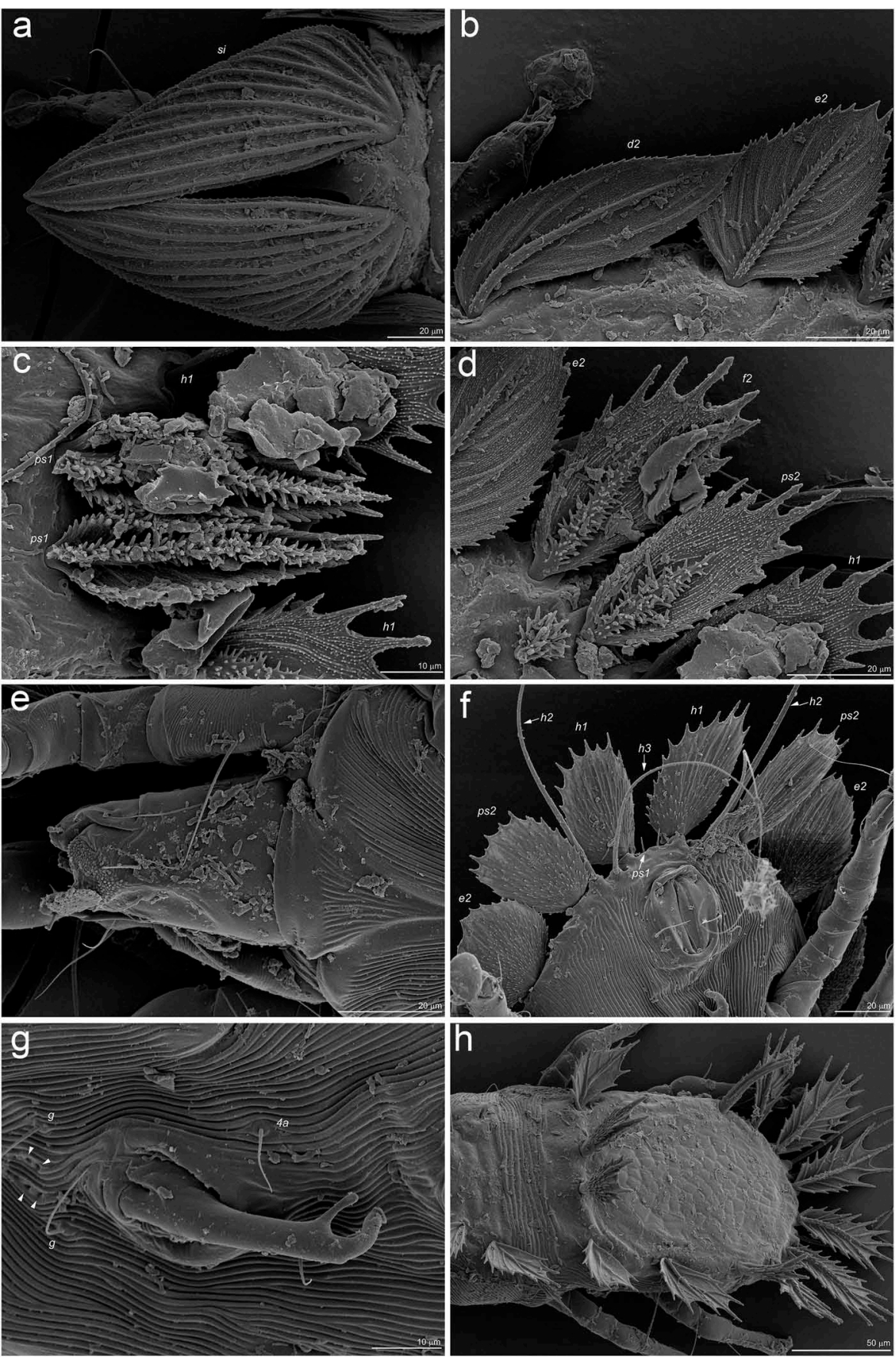

Figure 21. Opisthocomacarus umbellifer (Trouessart, 1899) (Pterolichidae). Low-temperature scanning micrographs: prodorsal setae si (a), latero-caudal setae $d 2$, e2 (b), setae ps1 (c), setae $e 2, f 2$, and ps2 of female (d); ventral view of gnathosoma of male (e); ventral view of hysterosoma of male (f); male aedeagus (g) (white arrows = genital papillae); dorsal view of tritonymph (h).

was also possible to confirm the absence of several setae (e.g. $f 2$, ps $1, g$ ) on females of this species. On Neumannella crypturella sp. nov., it was possible to clearly confirm the presence of the minute seta supracoxal scx (Figure 13(c), arrow), also very difficult to be detected by virtue of being localized in a prodorsal area with integumental folds, which often obscure its proper visualization. Oustaletia pegasus is observed using the LT-SEM for the first time. The peculiarity and uniqueness of this mite's morphology makes it easy to agree with its descriptor, who regarded it the most remarkable of all known feather mites (Trouessart 1885a). Finaly, although Opisthocomacarus umbellifer was previously observed in a SEM (Atyeo and Gaud 1971), details of its highly modified setae are revealed for the first time in high magnification (Figures 20 and 21). Maybe Walter and Proctor (2013) were not far from the truth in regarding feather mites as "perhaps the most fabulously ornamented of all Acari."

\section{Acknowledgements}

To Gustavo Pinto for collecting the dead specimen of Crypturellus parvirostris. To Drs Mark Judson (Muséum National d'Histoire Naturelle, Paris, France) and Didier Van den Spiegel (MRAC, Tervuren, Belgium) for allowing FAH to examine type specimens described by E.L. Trouessart and J. Gaud, respetively. To John Bates and Ben Marks (Field Museum of Natural History, Chicago) and Barry OConnor (University of Michigan, Ann Arbor), for allowing $\mathrm{FAH}$ to collect mites from the ornithological skins at the FMNH and UMMZ, respectively. To Chris Pooley, USDA-ARS for editing and arranging the LT-SEM image plates. FAH acknowledges funding from FAPESP - São Paulo Research Foundation (2011/50145-0). Mention of trade names or commercial products in this publication is solely for the purpose of providing specific information and does not imply recommendation or 
endorsement by the USDA; USDA is an equal opportunity provider and employer.

\section{Disclosure statement}

No potential conflict of interest was reported by the authors.

\section{Funding}

FAH acknowledges funding from Fundação de Amparo à Pesquisa do Estado de São Paulo [2011/50145-0].

\section{References}

Albuquerque DAD, Brener B, Menna-Barreto RFS, Brun SF. 2012. The first identification of Nymphicilichus perezae Mironov and Galloway, 2002 in cockatiels in Brazil and the first record of Psittophagus sp. Gaud and Atyeo, 1996 and cf. Dubininia sp. Vassilev, 1958 in cockatiels (Nymphicus hollandicus Kerr, 1792). Parasitology International 61:572-578.

Atyeo WT. 1988a. Feather mites of the Aralichus Canestrinii (Trouessart) complex (Acarina, Pterolichidae) from New World parrots (Psittacidae). I. From the genera Ara Lacépède and Anodorhynchus Spix. Fieldiana, Zoology 47:1-26.

Atyeo WT. 1988b. Aralichus porrectus (Mégnin \& Trouessart) and related feather mite species (Acarina, Pterolichidae) from parrots of the genus Brotogeris Vigors (Aves, Psittacidae). Systematic Parasitology 14:101-111. doi: 10.1007/BF00016904

Atyeo WT. 1992. The pterolichoid feather mites (Acarina, Astigmata) of the Megapodiidae (Aves, Galliformes). Zoologica Scripta 21:265-305.

Atyeo WT, Gaud J. 1966. The chaetotaxy of sarcoptiform feather mites (Acarina: Analgoidea). Journal of the Kansas Entomological Society. 39:337-346. Available from: http:// www.jstor.org/stable/25083524

Atyeo WT, Gaud J. 1971. Feather mites (Analgoidea: Pterolichidae) of the hoatzin (Aves: Galliformes). The American Midland Naturalist 86:152-159.

Atyeo WT, Gaud J, Humphreys WJ. 1972. The feather mite genus Freyanella Dubinin, 1953 (Analgoidea: Pterolichidae). Acarologia. 13:383-409.

Berla HF. 1960. Analgesoidea neotropicais. VII. Novas espécies de acarinos plumícolas. Anais da Academia Brasileira de Ciências. 32:95-105.

Castro EB, Ochoa R, Feres RJF, Beard J, Bauchan GR. 2015. Reinstatement of the genus Colopalpus Pritchard and Baker (1958) and re-description of Colopalpus matthyssei Pritchard and Baker (1958), the type species of the genus (Acari, Tenuipalpidae). International Journal of Acarology 41:310-328.

Dabert J. 2014. A new feather mite species of the genus Neumannella Trouessart, 1916 (Analgoidea, Dermoglyphidae) from the Red-winged Tinamou Rhynchotus rufescens (Temminck, 1815) (Aves, Tinamiformes) with remarks to the evolution of host-parasite associations of the genus. Acta Parasitologica 59:197-205.

Dabert J, Skoracki M. 2004. Two new species of the genus Neumannella Trouessart, 1916 (Analgoidea, Dermoglyphidae) from the tataupa tinamou Crypturellus tataupa (Temminck, 1815) (Aves, Tinamiformes). Acta Parasitologica 49:237-245.

Dubinin VB. 1951. Feather mites (Analgesoidea). Part I. Introduction to their study. Fauna URSS (Arachnides). 6:1-363.

Dubinin VB. 1955. New genera and species of feather mites. Trudy Zoologicheskogo. Instituta Akademii Nauk SSSR. 18:248-286.

Gaud J. 1982. Acariens sarcoptiformes plumicoles parasites des oiseaux Ciconiiformes d'Afrique. III. Parasites des Threskiornithidae. Revue Zoologique Africaine. 96:701-730.
Gaud J, Atyeo WT. 1996. Feather mites of the World (Acarina, Astigmata): the supraspecific taxa. Annales du Musée Royal de I'Afrique Centrale, Sciences Zoologiques. 277:1-193. (Pt. 1, text), 1-436 (Pt. 2, illustrations.

Gaud J, Atyeo WT, Berla HF. 1973. Acariens Sarcoptiformes plumicoles parasites des tinamous. Acarologia. 14:393-453.

Gaud J, Mouchet J. 1957. Acariens plumicoles (Analgesoidea) des oiseaux du Cameroun. I. Proctophyllodidae. Annales de Parasitologie Humaine et Comparée. 32:491-546.

Gaud J, Till WM. 1961. Suborder Sarcoptiformes. In: Zumpt F, editors. The arthropod parasites of vertebrates in Africa south of the Sahara (Ethiopian region). Vol. 1. Publications of the South African Institute for Medical Research. p. 180397. (9).

Griffiths DA, Atyeo WT, Norton RA, Lynch CA. 1990. The idiosomal chaetotaxy of astigmatid mites. Journal of Zoology 220:1-32.

Hernandes FA, Mironov SV. 2015. The feather mites of the hoatzin Opisthocomus hoazin (Müller) (Aves: Opisthocomiformes), with the description of two new genera and six new species (Acari: Analgoidea, Pterolichoidea). Zootaxa 4034:401-444.

Hernandes FA, Mironov SV, Bauchan GR, Ochoa RA. 2016a. A new asymmetrical feather mite of the genus Michaelia Trouessart, 1884 (Astigmata: Freyanidae) from the Neotropical cormorant, Phalacrocorax brasilianus (Pelecaniformes). Acarologia 56: 45-61.

Hernandes FA, Pedroso LGA. 2017. Two new feather mites of the genus Protonyssus Trouessart, 1916 (Acariformes: Xolalgidae) from Brazilian parakeets (Psittacidae), with a key to species. International Journal of Acarology 43:204-211.

Hernandes FA, Pedroso LGA, Bochkov AV. 2015. Carcinopodacarus polymorphus gen. nov., sp. nov. from Guira guira (Cuculiformes: Cuculidae) in Brazil-a first example of male polymorphism in the family Dermationidae (Acariformes: Analgoidea). Folia Parasitologica 62:1-9.

Hernandes FA, Pedroso LGA, Oniki-Willis Y. 2016b. Five new feather mites of the subfamily Pterodectinae (Acariformes: Astigmata: Proctophyllodidae) from passerines and hummingbirds (Aves) of Brazil. 2016. Zootaxa 4161:301-328.

Krantz GW, Walter DE. 2009. A manual of acarology. 3rd ed. Lubbock: Texas Tech University Press. p. 807.

Kudon LH. 1982. Platyacarus, a new genus of feather mites (Acarina: Proctophyllodidae). Journal of the Georgia Entomological Society. 17:333-337.

Mestre A, Mesquita-Joanes F, Proctor HC, Monrós JS. 2011. Different scales of spatial segregation of two species of feather mites on the wings of a passerine bird. Journal of Parasitology 97:237-244.

Mironov SV. 1996. On a validity of the genus Plicalloptes (Acarina: Analgoidea: Alloptidae). Parazitologiya. 30:216-222. (in Russian).

Mironov SV. 2002. Three new feather mite genera of the family Alloptidae (Acari: Astigmata) from the ibises (Ciconiiformes: Threskiornithidae). Acarina. 10:25-42.

Mironov SV. 2013. A taxonomic note on the type species of the feather mite genus Anisanchus Peterson et Atyeo, 1977 (Acariformes: Analgoidea: Alloptidae). Acarina. 21:133-134.

Mironov SV, Dabert J, Ehrnsberger R. 2005. Six new feather mite species (Acari: Astigmata) from the Carolina parakeet Conuropsis carolinensis (Psittaciformes: Psittacidae), an extinct parrot of North America. Journal of Natural History 39:2257-2278.

Mironov SV, Palma RL. 2006. Two new feather mite species (Acari: Analgoidea) from the Tuamotu sandpiper Aechmorhynchus parvirostris (Charadriiformes: Scolopacidae). Tuhinga. 17:49-59.

Norton R. 1998. Morphological evidence for the evolutionary origin of Astigmata (Acari: Acariformes). Experimental and Applied Acarology 22:559-594. 
Pérez TM. 1995. Seven species of Fainalges Gaud and Berla (Analgoidea, Xolalgidae) from Aratinga holochlora (Sclater) (Aves, Psittacidae). Zoologica Scripta 24:203-223.

Pérez TM, Atyeo WT. 1992. A review of the Xoloptoidinae (Acari, Pterolichidae) and the description of a new genus. Entomologische Mitteilungen Aus Dem Zoologischen Museum Hamburg. 10:209-220.

Trouessart EL. (1884) 1885a. Les Sarcoptides plumicoles. Révision du groupe des Analgesinae, et description d'espèces et genres nouveaux de la collection du Musée d'Angers. Journal de Micrographie. 9:63-70.

Trouessart EL. 1885b. Les acariens parasites des calaos, I'Oustaletia pegasus. La Nature. 2:24-26.

Trouessart EL, Neumann G. 1888. Diagnoses d'espèces nouvelles de Sarcoptides plumicoles (Analgesinae). Bulletin Scientifique de la France et de la Belgique. 19:325-380.

Walter DE, Proctor HC. 2013. Mites: ecology, evolution \& behaviourlife at a microscale. Springer. p. 486. doi:10.1007/978-94-007-7164-2 